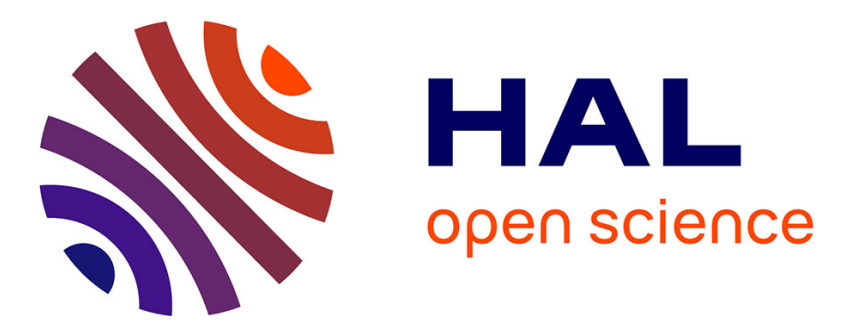

\title{
Solution structure of ace-AMP1, a potent antimicrobial protein extracted from onion seeds. Structural analogies with plant nonspecific lipid transfer proteins
}

S. Tassin, W.F. Broekaert, D. Marion, D.P. Acland, M. Ptak, F. Vovelle, P. Sodano

\section{To cite this version:}

S. Tassin, W.F. Broekaert, D. Marion, D.P. Acland, M. Ptak, et al.. Solution structure of ace-AMP1, a potent antimicrobial protein extracted from onion seeds. Structural analogies with plant nonspecific lipid transfer proteins. Biochemistry, 1998, 37 (11), pp.3623-3637. hal-02695322

\section{HAL Id: hal-02695322 \\ https://hal.inrae.fr/hal-02695322}

Submitted on 1 Jun 2020

HAL is a multi-disciplinary open access archive for the deposit and dissemination of scientific research documents, whether they are published or not. The documents may come from teaching and research institutions in France or abroad, or from public or private research centers.
L'archive ouverte pluridisciplinaire HAL, est destinée au dépôt et à la diffusion de documents scientifiques de niveau recherche, publiés ou non, émanant des établissements d'enseignement et de recherche français ou étrangers, des laboratoires publics ou privés. 


\title{
Solution Structure of Ace-AMP1, a Potent Antimicrobial Protein Extracted from
} Onion Seeds. Structural Analogies with Plant Nonspecific Lipid Transfer Proteins ${ }^{\dagger}$

\author{
Séverine Tassin, ${ }^{*, \neq}$ Willem F. Broekaert, ${ }^{\S}$ Didier Marion," David P. Acland, ${ }^{\perp}$ Marius Ptak,,,$+ \ldots$ \\ Françoise Vovelle,
}

Centre de Biophysique Moléculaire (CNRS) et Université d'Orléans, rue Charles Sadron, 45071 Orléans Cédex 02, France, Université d'Orléans, rue de Chartres, 45069 Orléans Cédex 02, France, F. A. Janssens Laboratory of Genetics, Katholieke Universiteit Leuven, K. Mercierlaan 92, B-3001 Heverlee, Belgium, Laboratoire de Biochimie et Technologie des Protéines, INRA, rue de la Géraudière, BP 1627, 44316 Nantes Cédex 05, France, and Jealott's Hill Research Station, Zeneca Agrochemicals, Bracknell Berkshire RG426ET, U.K.

Received September 22, 1997; Revised Manuscript Received December 23, 1997

\begin{abstract}
The three-dimensional solution structure of Ace-AMP1, an antifungal protein extracted from onion seeds, was determined using ${ }^{1} \mathrm{H}$ NMR spectroscopy and molecular modeling. This cationic protein contains 93 amino acid residues and four disulfide bridges. Its structure was determined from $1260 \mathrm{NOE}-$ derived distance restraints and 173 dihedral restraints derived from NOEs and ${ }^{3} J_{\mathrm{C}_{2} \mathrm{HNH}}$ coupling constants. The global fold involves four helical segments connected by three loops and a C-terminal tail without regular secondary structures, except for a $3_{10}$-helix turn and a $\beta$-turn. The most striking feature is the absence of any continuous cavity running through the whole molecule as found in recently determined structures of nonspecific transfer proteins extracted from wheat and maize seeds, although their global folds are very similar. Consistent with the absence of a cavity in the core of Ace-AMP1, it was found that this protein, in contrast to ns-LTPs, does not bind fluorescently labeled phospholipids in solution. On the other hand, Ace-AMP1 is able to interact with phospholipid membranes as shown by the release of carboxyfluorescein from the lumen of artificial liposomes and by the induction of alterations in fluorescence polarization of fluorescently labeled phospholipids embedded in artificial liposomes.
\end{abstract}

Various antimicrobial proteins have been proposed to be involved in the protection of seeds against potential microbial invaders during their germination on substrates rich in microorganisms. Since the initial discovery of the antimicrobial properties of thionins in $1942(1)$, other antimicrobial proteins have been isolated from plants such as $\beta-1.3$ glucanases $(2,3)$, permatins $(4)$, ribosome-inactivating proteins $(3,5)$. cysteine-rich antimicrobial peptides $(6-8)$. plant defensins $(9-11), 2 \mathrm{~S}$ albumins $(9,10)$, and several nonspecific lipid transfer proteins (ns-LTPs) $(12,13)$. Recently, Cammue et al. (14) have isolated a protein from onion seeds, named Ace-AMP1, which exhibits a higher antimicrobial activity than $R s$-ns-LTP, a ns-LTP-like protein extracted from radish seeds (9). Ace-AMPI is active against aumerous fungi at concentrations $\leq 10 \mu \mathrm{g} / \mathrm{mL}$, and in contrast to that of Rs-ns-LTP, its activity is weakly affected by inorganic cations at physiological concentrations (14). Ace-

'This work was supported by the Centre National de la Recherche Scientifique (CNRS), the Université d'Orléans, the Région Centre, and the Institut National de la Recherche Agronomique (INRA). It forms part of Séverine Tassin's thesis supported by a Région Centre grant.

* Correspondence should be addressed to Centre de Biophysique Moléculaire, rue Charles Sadron, 45071 Orléans, France. Telephone: (33) 02382555 74. Fax: (33) 023863 15 17. E-mail: tassin@enrssleans.fr.

₹Centre de Biophysique Moléculaire (CNRS) et Université d'Orléans.

Katholieke Universiteit Leuven.

"Laboratoire de Biochimie et Technologie des Protéines, INRA.

$\perp$ Zeneca Agrochemicals.

"Université d'Orléans.
AMP1 is synthesized with an $\mathrm{N}$-terminal signal peptide and a C-terminal propeptide of 12 amino acid residues which are both absent from the mature protein. The C-terminal propeptide of Ace-AMP1 precursor is rich in hydrophobic and acidic residues as found in C-terminal propeptides of precursors of many vacuolar plant proteins (15). Such C-terminal propeptides have often been shown to be determinants for targeting the proteins to the vacuole (16. 17). The subcellular location of Ace-AMPl remains nevertheless to be determined.

Ace-AMPI is a 93-residue protein. including eight cysteines engaged in four disulfide bridges. The positions of the eight cysteine residues are similar to those found in the sequences of ns-LTPs. A sequence alignment between AceAMP1 and maize ns-LTP reveals 32\% identity and $49 \%$ similarity (18). On the basis of such sequence similarities. Ace-AMPI could be considered a member of the ns-LTP family. Nevertheless, it does not exhibit the characteristic property of these proteins, i.e., the ability to transfer lipids between membranes of vesicles or organelles in vitro (14). The most striking features of the Ace-AMPI sequence are the high percentage of arginine residues (20\%) and the presence of a tryptophan doublet in the C-terminal region.

We have previously determined the solution structures of two ns-LTPs extracted from wheat (19) and maize seeds (20). At the same time, the X-ray structures of maize ns-LTP and its complex with a lipid were determined by Shin et al. (2l). Recently, the solution structures of a barley ns-LTP (22) and 
its complex with palmitoyl coenzyme A were established from ${ }^{1} \mathrm{H}$ and ${ }^{13} \mathrm{C}$ NMR data (23). Similar folds involving four helixes wound in a right-handed superhelix and a C-terminal region devoid of regular secondary elements were found in these three-dimensional structures. The structures of wheat and maize ns-LTPs showed an internal elongated hydrophobic cavity running through the whole molecule $(19-21)$ which has been shown to be the site for lipid binding $(20,21)$. More recently, we have proposed a model of the structure of Ace-AMP1 by using homology modeling (I8).

Despite the extensive study of the structure of ns-LTPs using a variety of techniques, a debate is still open on their possible role in vivo. Different functions have been proposed such as playing a role in the formation of cutin by transporting the hydrophobic cutin monomers to the apoplast (24) or playing a role as antimicrobial agents in the defense of plants against pathogens $(9,13,25)$.

In this paper, we report on the three-dimensional structure of Ace-AMP1 in solution determined on the basis of NMR spectroscopy experiments. This study enables us to point out striking analogies between the global folds of Ace-AMP1 and ns-LTPs but also important differences in the organization of their internal cavities which are probably related to their capacity to bind lipids.

\section{MATERIALS AND METHODS}

Lipid-Ace-AMPI Interaction Studies. Fluorescence emission spectra of Ace-AMP1 were recorded with an Amincon SLM 4800 spectrofluorometer. Excitation and emission wavelengths were set to 295 and $335 \mathrm{~nm}$ (slits of $4 \mathrm{~nm}$ ), respectively. For the titration of proteins with various lipids. the following procedure was used. Two to four microliters of aqueous dispersions of wheat total polar lipids, phospholipids in $10 \mathrm{mM}$ sodium phosphate buffer at $\mathrm{pH} 7.0$ (either 1 or $10 \mathrm{mg} / \mathrm{mL}$ ), was added stepwise to $1 \mathrm{~mL}$ of protein solution $(0.1 \mathrm{mg} / \mathrm{mL}, 8 \mu \mathrm{M})$ in the same buffer. After incubation for $1 \mathrm{~min}$, the fluorescence emission spectra were recorded at $20{ }^{\circ} \mathrm{C}$. Fluorescence data were corrected for background signals by using the corresponding lipid solutions alone.

Lipid transfer assay was performed using fluorescent -phospholipid probes 1-palmitoyl-2-pyrenyldecanoyl-sn-glycero-3-phosphocholine (pyr-PC) and the corresponding phosphoglycerol derivative (pyr-PG) as previously described (26, 27). Lipid binding was tested by adding different ns-LTPs (wheat, maize, and barley) and Ace-AMP1 to $1.5 \mathrm{~mL}$ of a liposomal suspension of $1 \mu \mathrm{M}$ pyr-PC or pyr-PG. In the binding assay, the final protein to fluorescent probe molar ratio was about 5 . In both fluorescence transfer and binding assays, the excitation wavelength was set to $346 \mathrm{~nm}$ (4 nm slit) and the emission wavelength was set to $378 \mathrm{~nm}$ ( $4 \mathrm{~nm}$ slit). All measurements were carried out at $25^{\circ} \mathrm{C}$.

The effect of proteins on lipid dynamics was studied by fluorescence polarization of a lipophilic probe, diphenylhexatriene (DPH), embedded within the hydrophobic core of phospholipid bilayers. Excitation and emission wavelengths were set to 360 and $435 \mathrm{~nm}$ (band width of $4 \mathrm{~nm}$ ), respectively. Measurements of the fluorescence intensities detected through polarizers oriented parallel $\left(I_{\| 1}\right)$ and perpendicular $\left(I_{1}\right)$ to the plane of polarization of the excitation light beam allowed us to calculate the steady state polariza-tion parameter $P\left[=\left(I_{\|}-I_{\perp}\right) /\left(I_{\|}+I_{\perp}\right)\right]$. For DPH labeling, $50 \mu \mathrm{L}$ of a DPH solution $(17 \mu \mathrm{g} / \mathrm{mL})$ diluted in methylene chloride was added to $500 \mu \mathrm{L}$ of the lipid solution ( $1 \mathrm{mg}$ / $\mathrm{mL}, \mathrm{DPH} /$ lipid ratio $\sim 1 / 250$ ). After drying, $1.5 \mathrm{~mL}$ of the $10 \mathrm{mM}$ sodium phosphate buffer at $\mathrm{pH} 7.0$ was added and the solution was mixed as described above. One milliliter of a diluted solution in phosphate buffer was poured into a quartz cuvette, and titration was performed by adding stepwise a protein solution $(1 \mathrm{mg} / \mathrm{mL})$ in phosphate buffer. The polarization data were recorded before and after the transition temperature of DMPG and DMPC $\left(23^{\circ} \mathrm{C}\right)$ from 15 to $45^{\circ} \mathrm{C}$.

Carboxyfluorescein (CF) release from liposomes was performed according to a modification of the procedure described by Wilschut (28). Briefly, a $50 \mathrm{mM}$ solution of HPLC-purified carboxyfluorescein (Molecular Probes) in 5 mM HEPES containing $1 \mathrm{mM}$ EDTA was adjusted to $\mathrm{pH}$ 7.4 with $1 \mathrm{~N} \mathrm{NaOH}$. Six hundred microliters of this solution was added to $2.3 \mathrm{mg}$ of a dry equimolar mixture of eggPG and eggPC (Sigma-Aldrich) and the mixture vortexed until all the phospholipids were dispersed. This solution was then extruded under high pressure through a $400 \mathrm{~nm}$ polycarbonate filter. Large unilamellar vesicles with encapsulated CF were separated from nonencapsulated CF by size exclusion chromatography on a PD-10 (Pharmacia) column eluted with HEPES buffer (5 mM HEPES, $1 \mathrm{mM}$ EDTA, and $100 \mathrm{mM}$ $\mathrm{NaCl}$ at $\mathrm{pH} 7.4$ ). For the $\mathrm{CF}$ release assay, the liposome solution was diluted in HEPES buffer so the absorbance would be below 0.2 at $493 \mathrm{~nm}$. The kinetics of CF release were recorded by the fluorescence increase at $520 \mathrm{~nm}$ (excitation at $490 \mathrm{~nm}$ ). One hundred percent release was obtained by lysing vesicles in the presence of $1 \%$ Triton $\mathrm{X}-100$.

NMR Experiments. Ace-AMP1 was purified from onion (Allium cepa L.) seeds as previously described (14). The NMR sample was prepared from lyophilized material to make up a $3 \mathrm{mM}$ solution in a mixture of $90 \% \mathrm{H}_{2} \mathrm{O}$ and $10 \% \mathrm{D}_{2} \mathrm{O}$. The $\mathrm{pH}$ was subsequently adjusted to 5.0.

All NMR measurements were performed on a Bruker AMX $500 \mathrm{MHz}$ NMR spectrometer equipped with a threeaxis field gradient unit. Quadrature detection in the indirectly detected dimensions was performed using the States method (29). NMR spectra were processed using the UXNMR program from Bruker on a X32 workstation. The following experiments were carried out at a temperature of $308 \mathrm{~K}$ : double-quantum COSY (2Q-COSY) with a mixing time of $30 \mathrm{~ms}$, total correlation spectroscopy (clean-TOCSY) with a $90 \mathrm{~ms}$ mixing time performed with a MLEV17 sequence (spin-lock field of approximately $10 \mathrm{kHz}$ ) (30), purged COSY (P-COSY) (3I), triple-quantum-filtered COSY (TQFCOSY) (32), relayed COSY (33) with a $40 \mathrm{~ms}$ relay period, and NOESY with a $60 \mathrm{~ms}$ mixing time. Additional NOESY experiments with a $200 \mathrm{~ms}$ mixing time were carried out at temperatures of 298,308 , and $318 \mathrm{~K}$. In all cases, the water signal was suppressed prior to the free induction decay detection by using the WATERGATE sequence (34) in which the selective inversion was achieved through a $3-9-$ 19 composite pulse and an interpulse delay of $250 \mathrm{~ms}$. In TOCSY and COSY experiments, a weak field (approximately $10 \mathrm{~Hz}$ ) presaturation applied during the relaxation period was followed by a SCUBA sequence (35). The measurements 
of proton exchange rates were performed at $308 \mathrm{~K}$ as follows. The protein sample in $\mathrm{H}_{2} \mathrm{O}$ first lyophilized and then dissolved in $\mathrm{D}_{2} \mathrm{O}$ at $273 \mathrm{~K}$ was placed in a preshimmed spectrometer approximately $15 \mathrm{~min}$ after dissolution. Two NOESY spectra were acquired, one short ( $4 \mathrm{~h}$ ) and one long (17 h), with a mixing time of $200 \mathrm{~ms}$, which was followed by a TOCSY experiment with a mixing time of $90 \mathrm{~ms}$.

All spectra were recorded with a spectral width of 7052 $\mathrm{Hz}$ in both dimensions and $2048 \times 650$ time domain data points, except for NOESY experiments used for the structure calculations which were acquired with $4096 \times 650$ data points. Sine bell apodization functions were used prior to Fourier transformation. Application of zero-filling resulted in $2 \mathrm{~K} \times 1 \mathrm{~K}$ data points for all spectra and $4 \mathrm{~K} \times 1 \mathrm{~K}$ real points for NOESY spectra used for structure calculations.

Modeling of the Three-Dimensional Structure. Models of the Ace-AMP1 three-dimensional structure in solution were built using the hybrid method of distance geometry and the simulated annealing protocol (36) on Silicon Graphics workstations. The assignment of all NOESY cross-peaks was obtained with repeated rounds of structure calculations with DIANA $(37,38)$ and with ASNO (39) software packages. The cross-peak volumes were integrated from the NOESY spectrum recorded with a $60 \mathrm{~ms}$ mixing time using EASY (40). Peak volumes were translated into upper limit distance restraints using the CALIBA program $(37,38)$ with an upper distance limit of $5.0 \AA$ for the weakest volumes. and the strongest $\mathrm{NH}_{i}-\mathrm{NH}_{i+1}$ connectivity in regular helixes was used as a reference. To take spin diffusion effects into account, cross-peaks appearing on the $200 \mathrm{~ms}$ mixing time NOESY spectrum and absent on the $60 \mathrm{~ms}$ NOESY spectrum were further considered and converted into a fixed distance of $6.0 \AA$, irrespective of the cross-peak volume intensity. A first set of structures was generated with DIANA and was used to redefine the 10 calibration classes of the CALIBA program. The final data set consisted of 1260 distance restraints, including 220 intraresidual, 320 sequential, 339 medium-range $(|i-j| \leq 5)$, and 378 long-range distance restraints. Sxity-six ${ }^{3} J_{\mathrm{C}_{3} \mathrm{HNH}}$ coupling constants were deduced from the NOESY spectrum using the back Fourier transform procedure of the INFIT program (4l) and were used together with the distance restraints to generate $76 \phi .76 \psi$, and 15 $\chi^{\prime}$ torsion angle restraints with the HABAS program (37). Thirty-six prochiral groups were stereospecifically assigned with the GLOMSA program (37). Hydrogen bonds found by DIANA in a majority of structures during the different ounds of calculations were progressively introduced as jestraints. They were converted into upper bond distance limits of 3.5 and $2.5 \AA$ and lower bond distance limits of 2.7 and $1.8 \AA$ for $\mathrm{CO}-\mathrm{N}$ and $\mathrm{CO}-\mathrm{HN}$. respectively. To define the four disulfide bridges, distance restraints were added in the following range: $1.9-2.1 \AA$ for $S \gamma(i)-\mathrm{S} \gamma(j)$ and $2.5-3.5 \AA$ for $\mathrm{C} \beta(i)-\mathrm{S} \gamma(j)$ and $\mathrm{C} \beta(j)-\mathrm{S} \gamma(i)$.

Starting from 200 randomized structures and keeping only unambiguously defined restraints, a first set of conformations vas obtained using the DIANA program. The 30 structures vith the lowest target function were selected for further calculations using the REDAC strategy (38). Additional restraints were incorporated in successive stages according to the concept of structure-aided assignment of ambiguous NOE cross-peaks with the ASNO program (39). Each new set of restraints was used as input for a new round of calculation, and this protocol was repeated eight times until all NOESY cross-peaks were assigned.

The 30 structures with lowest target function (TF $<5 \AA^{2}$ ) were ther subjected to simulated annealing using the XPLOR 3.1 program (42). Subsequently, 15 structures, exhibiting the smallest restraint violations and presenting at least $65 \%$ of their $(\phi$ and $\psi$ ) torsional angles in the most favorable region of the Ramachandran map, were minimized using the CHARMM force field (43) implemented in XPLOR. The PROMOTIF (44) and PROCHECK programs (45) were used to analyze and to check the quality of the structures.

\section{RESULTS}

\section{Sequence-Specific Assignments}

An almost complete sequence-specific assignment of the ${ }^{1} \mathrm{H}$ NMR spectra (Supporting Information) was performed according to the well-established sequential assignment procedure of Wüthrich (46), using a combination of COSY, TOCSY, 2Q-COSY, and NOESY two-dimensional experiments recorded at a temperature of $308 \mathrm{~K}$. Due to severe redundancy of some amino acid residues in the primary structure of the protein (19 arginines and 9 prolines), a sequential assignment pathway was also followed on NOESY spectra recorded at 298 and $318 \mathrm{~K}$. The good dispersion of the amide ' $\mathrm{H}$ resonances. as shown in Figure 1 where two spectral regions of a NOESY spectrum recorded at $308 \mathrm{~K}$ with a $200 \mathrm{~ms}$ mixing time are plotted. led to an almost continuous stretch of sequential NOEs over the whole molecule. The only exception concerned the C-terminal region where the assignment of the tripeptide Ile87-GIn88Cys 89 remained very ambiguous due to the high exchange rate of the amide protons and to peak overlapping in the aliphatic proton resonance region. The assignments of the five glycine $\mathrm{C \alpha H}$, were confirmed through a $2 \mathrm{Q}-\mathrm{COSY}$ experiment, since the glycine remote connectivities resonated in a typical free spectral region. In addition. this experiment confirmed the degeneracy of $\mathrm{CaH}_{2}$ proton resonances of Gly52. A relayed COSY spectrum recorded at $308 \mathrm{~K}$ confirmed the assignments of the $\mathrm{C} \beta \mathrm{H}$ protons through a relay to amide protons. The nine prolines of Ace-AMPl were all found in the trans configuration characterized by. $\mathrm{C} \alpha \mathrm{H}(i-1)-{\mathrm{C} \delta \mathrm{H}_{2}}_{2}(i)$ and $\mathrm{NH}\left(i-11-{\mathrm{C} \delta \mathrm{H}_{2}}_{2}(i) \mathrm{NOE}\right.$ connectivities.

\section{Secondary Structures}

The amide exchange data and the short- and medium-range dipolar connectivities observed for the backbone protons in a $200 \mathrm{~ms}$ NOESY spectrum in $\mathrm{H}_{2} \mathrm{O}$ are summarized in Figure 2. The presence of four helical secondary structure elements is first derived from a dense array of characteristic NOEs and from stretches of slowly exchanging backbone amide protons. Successive rounds of calculations led us to define more accurately the extent of the four $\alpha$-helixes encompassing residues Cys4-Leu19 (H1), Ala25-Leu34 (H2). Leu42Asn57 (H3), and Arg65-Arg74 (H4). Most hydrogen bonds characterizing these helixes are present in a majority of selected structures and are all supported by slow $\mathrm{NH}^{i} \mathrm{H}-$ ${ }^{2} \mathrm{H}$ exchange rates and by low values of $J_{\mathrm{C}_{\mathrm{H}} \mathrm{HNH}}$ coupling constants (Figure 2). The only discrepancy is found for the coupling constants of some residues in the $\mathrm{H}+$ helix which 


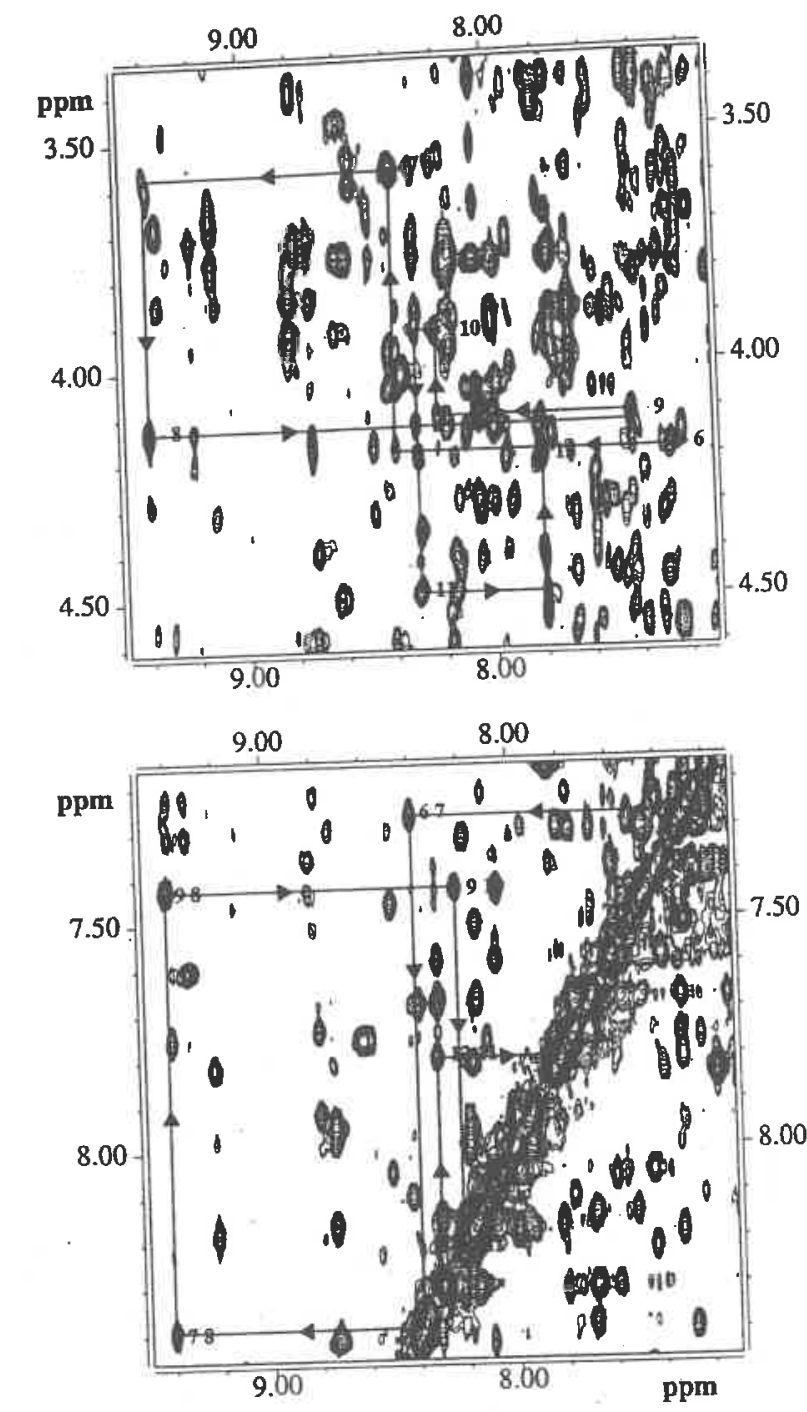

FIGURE 1: Two spectral regions of a NOESY spectrum of AceFIGURE 1: $9 / 1 \mathrm{H}_{2} \mathrm{O} / \mathrm{D}_{2} \mathrm{O}$ at $308 \mathrm{~K}$ with a $200 \mathrm{~ms}$ mixing time and AMP1 in $9 / 1 \mathrm{H}_{2} \mathrm{O} / \mathrm{D}_{2} \mathrm{O}$ at $308 \mathrm{~K}$ with a 200 me the

starts after a proline residue (Pro64) and which contains a proline residue (Pro70) in the middle of its sequence (see below). The Asn75-Asn93 fragment includes extended conformations and two well-organized fragments: a 310 -helix turn (Val78-Phe81) and a $\beta$-tum (Arg84-Ile87).

\section{Disulfide Bridges}

The three-dimensional structure of Ace-AMP1 is stabilized by four disulfide bridges (14). In the absence of chemical characterization, these covalent links were determined according to the following procedure. The distance between the $\mathrm{H} \beta$ protons of one Cys residue and the $\mathrm{H} \alpha$ proton of the second one engaged in the same disulfide bridge is in a range in which NOEs can be theoretically detected (47). Nevertheless, local dynamics or a special conformation can strongly reduce these NOEs, thus hampering their detection. Several inter-cysteine NOE connectivities allowed us to identify clearly two disulfide bridges: Cys 14-Cys27 and Cys28Cys73 (Table 1). Since in the Cys4-Cys49 bridge the $\beta$-proton resonances of the two cysteine residues almost overlap, inter-residue connectivities could not be unambiguously assigned. This bridge was deduced indirectly via long- range connectivities between Cys49 and Val7 or Asn8 residues which are adjacent to Cys4 in the $\mathrm{H} 1$ helix. The only possibility for the last bridge was Cys47-Cys89 even if any Cys 89 proton resonances could be identified. The proposed disulfide pairings, Cys4-Cys49, Cys14-Cys27, Cys28-Cys73, and Cys47-Cys89, are fully compatible with the distance restraints (Table 2) and with the disulfide pattern found for all known ns-LTP structures (19-22).

\section{Three-Dimensional Structure}

Quality of the Structure. Table 2 gives an evaluation of the quality and precision of the structures determined from NMR data. In the 15 selected structures, there is no structure with distance violations larger than $0.4 \AA$ and the average number of violations larger than $0.3 \AA$ is only 0.2 . Considering the number of NOEs per residue (Figure 3 ), the secondary structure elements are particularly well-defined, in contrast with the loop and turn regions where some variability is observed. In the four helixes $\mathrm{H} 1-\mathrm{H} 4$, the average pairwise root-mean-square deviations (rmsds) are $0.62 \AA$ for the backbone atoms $\left(\mathrm{N}, \mathrm{Ca}\right.$, and $\left.\mathrm{C}^{\prime}\right)$ and $1.13 \AA$ for all heavy atoms. These values drop to 0.44 and $0.97 \AA$, respectively, when the rmsds are calculated with respect to the average structure. The highest rmsd values are confined to the loops connecting the helixes and to the very end of the C-terminal region (Figure 3). All these values are typical of high-resolution NMR structures. An efficient assessment of the structure quality may be obtained from the distribution of the residues in a ( $\phi$ vs $\psi$ ) Ramachandran plot (48). PROCHECK concludes that $70 \%$ of the ( $\phi$ and $\psi$ ) pairs of the 15 minimized structures of Ace-AMP1 lie within the most energetically allowed regions and $29 \%$ in the extended favorable regions.

Global Fold. The global fold of Ace-AMP1 shown in Figure 4 is stabilized by four disulfide bonds and involves four amphipatic helixes $(\mathrm{HI}-\mathrm{H} 4)$ and a $\mathrm{C}$-terminal segment defined above. As in all ns-LTP structures, the Prol3 residue produces a break in the hydrogen bond network of helix $\mathrm{H} 1$ and induces a kink of about $20^{\circ}$. A PROCHECK analysis of the 15 best structures showed that the $\mathrm{H} 2$ helix (residues $25-34$ ) ends up at residue Leu34 and displays a characteristic $\alpha$-helical hydrogen bond pattern. The two next residues, $\operatorname{Arg} 35\left(\phi=-30.5^{\circ}\right.$ and $\psi=-32.3^{\circ} ; \phi$ and $\psi$ averaged over the 15 structures) and Phe36 $\left(\phi=-76.3^{\circ}\right.$ and $\psi=$ $-24.9^{\circ}$ ), are located in the helical regions of the Ramachandran map, but they are not involved in regular hydrogen bonds with the preceding residues. The $\mathrm{N}$ terminus of helix $\mathrm{H} 2$ is connected to helixes $\mathrm{H} 1$ and $\mathrm{H} 4$ through two disulfide bridges, Cys 27-Cys14 and Cys28-Cys73. The third helix H3 (residues $42-57$ ) is interrupted by a proline residue (Pro58). However, in 10 out of the 15 selected structures, the three residues following Pro58 are involved in a supplementary $\alpha$-helical turn (residues 59-62) stabilized by a hydrogen bond between the carbonyl of Pro58 and the amide proton of Arg62. The NH proton of Leu60 was found to exchange slowly, and in all structures, this fragment is linked to the $\mathrm{H} 3$ helix by a hydrogen bond with the carbonyl of Asn57. The Pro58 residue induces a severe kink of about $90^{\circ}$ between helix $\mathrm{H} 3$ (residues $42-57$ ) and the supplementary $\alpha$-helical turn (residues 59-62). As is often observed in distorted helixes of ns-LTPs, high ${ }^{3} J_{\mathrm{CahNH}}$ coupling constants are found for the residues preceding prolines ( 8.2 
10

20

30

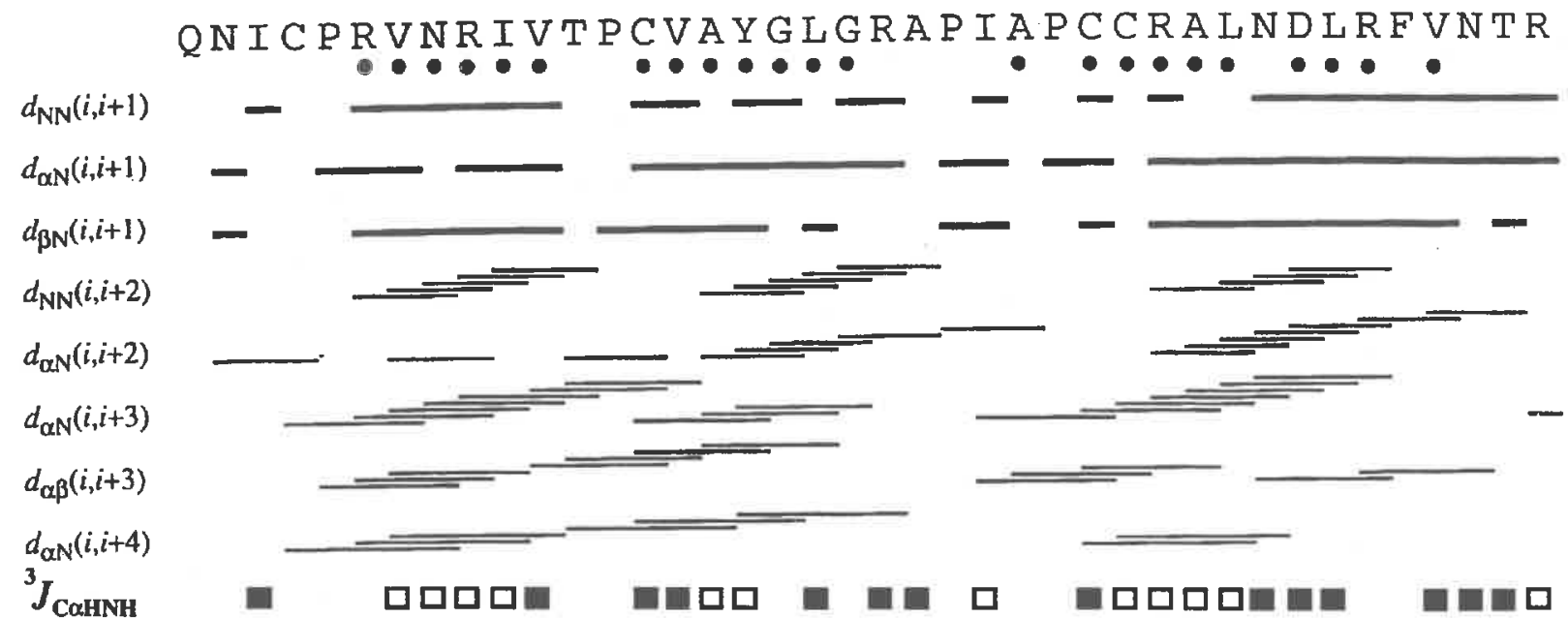

50

60

70

80

NLRRAACRCLVGVVNRNPGLRRNPRFQNIPRDCRNTFVRP

$d_{\mathrm{NN}}(i, i+1)$

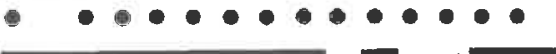

$d_{\alpha \mathrm{N}}(i, i+1)$

$d_{\beta N}(i, i+1)$

$d_{\mathrm{NN}}(i, i+2)$

$d_{\alpha N}(i, i+2)$

$d_{\alpha N}(i, i+3)$

$d_{\alpha \beta}(i, i+3)$

$d_{\alpha \mathrm{N}}(i, i+4)$

${ }^{3} J_{\text {CaHNII }}$
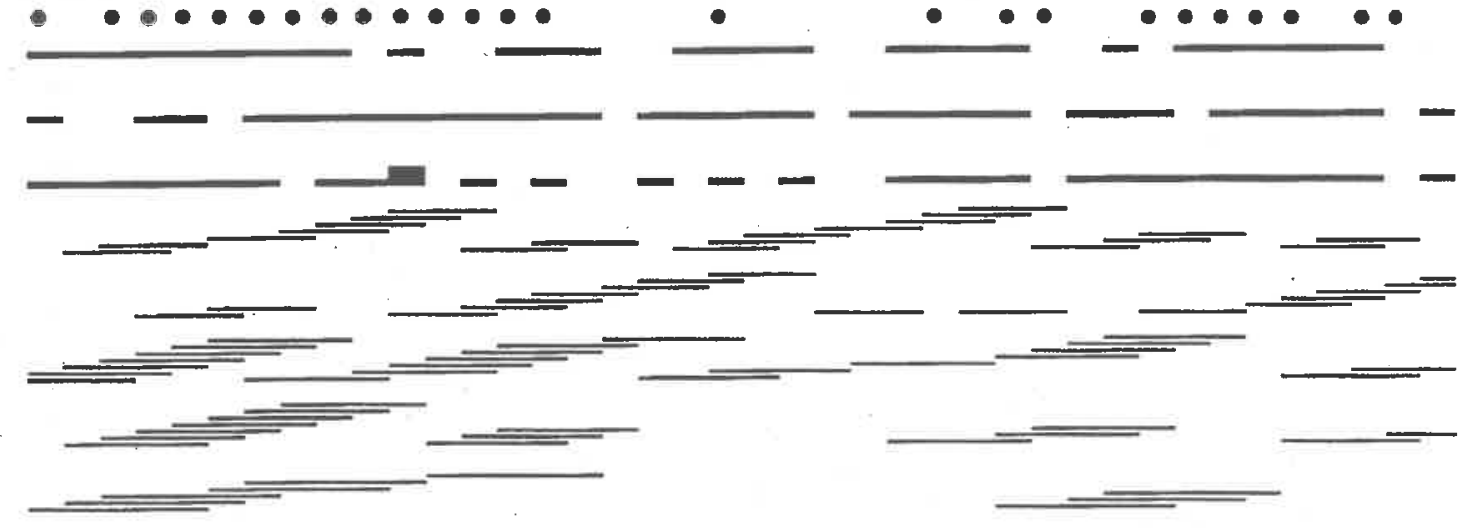

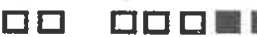

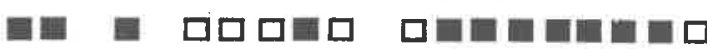

90

FWWRPRIQCGRIN

$$
\begin{aligned}
& d_{\mathrm{NN}}(i, i+1)= \\
& d_{\alpha \mathrm{N}}(i, i+1)= \\
& d_{\beta N}(i, i+1)= \\
& d_{\mathrm{NN}}(i, i+2) \\
& d_{\alpha \mathrm{N}}(i, i+2)= \\
& d_{\alpha \mathrm{N}}(i, i+3)- \\
& d_{\alpha \beta}(i, i+3)- \\
& d_{\alpha \mathrm{N}}(i, i+4) \\
& 3_{\mathrm{C} \alpha \mathrm{HNH}}
\end{aligned}
$$$$
d_{\alpha N}(i, i+3)-
$$

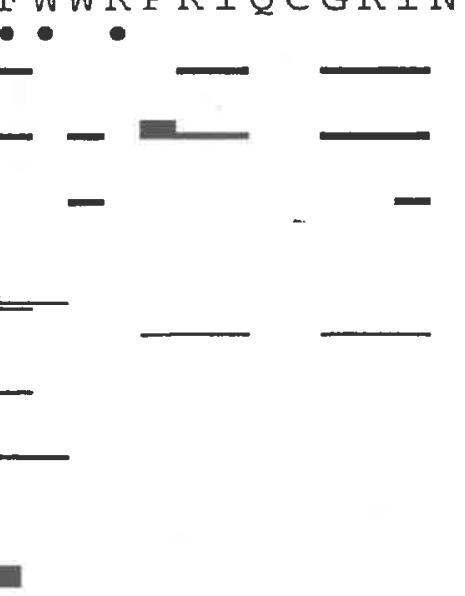

FIGURE 2: Summary of the data on the sequentials NOE, slow amide proton exchange rates (marked with a 9 ), and ${ }^{3} J_{\mathrm{C}_{\mathrm{H}} \mathrm{HH}}$ coupling instants (black for ${ }^{3} J_{\mathrm{C}_{\mathrm{a}} \mathrm{HNH}}>8 \mathrm{~Hz}$, gray for $6 \mathrm{~Hz}<{ }^{3} J_{\mathrm{C}_{\mathrm{i}} \mathrm{HNH}}>8 \mathrm{~Hz}$, and white for ${ }^{3} J_{\mathrm{C}_{\mathrm{H}} \mathrm{HNH}}<6 \mathrm{~Hz}$ ) determined by NMR for $A e^{-} e^{-A M P I}$

and $10.8 \mathrm{~Hz}$ for Arg56 and Asn57, respectively). The $\mathrm{H} 3$ helix is linked to helix $\mathrm{Hl}$ and the C-terminal segment through two disulfide bridges, Cys4-Cys49 and Cys47Cys89. The last helix, $\mathrm{H} 4$, is preceded by a $\gamma$-turn stabilized by a hydrogen bond between the carbonyl of Asn 63 and the annide proton of Arg65. In this helix, including residues $65-$ 74. the hydrogen bond network is somewhat irregular showing both $3_{1)^{-}}$and $\alpha$-helical characteristics as previously observed for the wheat ns-LTP structure (19). These irregularities arise from the presence of two proline residues. 
3628 Biochemistry, Vol. 37, No. 11, 1998

\begin{tabular}{|c|c|c|}
\hline disulfide bridge & \multicolumn{2}{|c|}{ inter-residue NOE connectivity } \\
\hline Cys4-Cys49 & $\begin{array}{l}\text { QG1 Val7 } \\
\text { QG1 Val7 } \\
\text { QG2 Val7 } \\
\text { QG2 Val7 } \\
\text { HB2 Asn8 }\end{array}$ & $\begin{array}{l}\text { HB2 Cys } 49 \\
\text { HB3 Cys } 49 \\
\text { HB2 Cys } 49 \\
\text { HB3 Cys } 49 \\
\text { HA Cys } 49 .\end{array}$ \\
\hline Cys14-Cys27 & $\begin{array}{l}\text { HA Cys } 14 \\
\text { QB Cys } 14 \\
\text { HA Cys } 14 \\
\text { HN Cys } 14 \\
\text { HN Cys } 14\end{array}$ & $\begin{array}{l}\text { HB3 Cys27 } \\
\text { HB2 Cys27 } \\
\text { HN Cys27 } \\
\text { HB3 Cys27 } \\
\text { HB2 Cys27 }\end{array}$ \\
\hline Cys28-Cys 73 & HA Cys28 & HB2 Cys73 \\
\hline
\end{tabular}

Table 2: Structural Statistics of the 15 Best Structures of Ace-AMP1

\begin{tabular}{|c|c|c|}
\hline & mean number & $\min , \max$ \\
\hline $\begin{array}{l}\text { Mean Number of Violati } \\
\text { distance restraints of }>0.3 \AA \\
\text { distance restraints of }>0.2 \AA \\
\text { angle restraints of }>10^{\circ}\end{array}$ & $\begin{array}{c}\text { ons of Experimental Re } \\
0.20 \\
1.40 \\
4.46\end{array}$ & $\begin{array}{r}\text { traints } \\
0,1 \\
0,3 \\
2,7\end{array}$ \\
\hline $\begin{array}{l}\text { Deviation from } \\
\text { bond distances of }>0.05 \AA \\
\text { angles of }>10^{\circ}\end{array}$ & $\begin{array}{c}\text { Idealized Geometry } \\
5.80 \\
4.00\end{array}$ & $\begin{array}{l}4,9 \\
2,9\end{array}$ \\
\hline $\begin{array}{l}\text { most favorable regions } \\
\text { additional regions }\end{array}$ & $\begin{array}{r}\text { lachandran } \\
70 \% \\
29 \%\end{array}$ & $\begin{array}{l}72,65 \\
31,26\end{array}$ \\
\hline & $\begin{array}{l}\text { rmsd from the } \\
\text { average structure }(\AA)\end{array}$ & $\begin{array}{l}\text { pairwise } \\
\text { rmsd }(\AA)\end{array}$ \\
\hline $\begin{array}{l}\text { backbone }(1-93) \\
\text { helixes } \\
\text { H1 }(4-19) \\
\text { H2 }(25-34) \\
\text { H3 }(42-57) \\
\text { H4 }(65-74) \\
\text { C-terminal region }(75-93)\end{array}$ & $\begin{array}{l}1.11 \pm 0.17 \\
0.44 \pm 0.04 \\
0.31 \pm 0.07 \\
0.29 \pm 0.09 \\
0.30 \pm 0.07 \\
0.18 \pm 0.07 \\
1.26 \pm 0.36\end{array}$ & $\begin{array}{l}1.61 \pm 0.41 \\
0.62 \pm 0.08 \\
0.45 \pm 0.10 \\
0.41 \pm 0.15 \\
0.36 \pm 0.09 \\
0.23 \pm 0.08 \\
1.78 \pm 0.75\end{array}$ \\
\hline
\end{tabular}

Pro64 and Pro70. The C-terminal segment (residues 7593) contains one $3_{10}$-helical turn (residues $78-81$ ) and a $\beta$-tum (residues $84-87$ ). Its first part is packed against the H4 helix, whereas its last part is approximately parallel to the $\mathrm{H} 3$ helix.

Disulfide Bridges and Side Chains. The conformations adopted by the four disulfide bridges are reported in Table 3. The Cys28-Cys73 bridge experiences two equally populated conformations, whereas the Cys 14-Cys 27 one adopts one well-defined conformation. Conversely, the ill experimental definition of Cys 4 and Cys89 residues leads to variable conformations of the Cys4-Cys49 and Cys47Cys 89 bridges. All cysteines but Cys 89 adopt staggered orientations around the $\mathrm{C}_{\alpha}-\mathrm{C}_{\beta}$ bond, and Cys 14, Cys 47, and Cys49 residues are well-defined $\left(\chi^{1}<0.1\right)$ (Figure 3 ). Moreover, for the first three disulfide bridges, Cys4-Cys 49 , Cys 14-Cys27, and Cys28-Cys73, $\chi^{\text {ss }}$ angles are very close to the expected values for energetically favorable conformers, i.e., $\pm 90^{\circ}$ (49).

Most side chain conformations are well-defined since $63 \%$ of the $\chi^{1}$ circular variances are lower than 0.1 (Figure 3 ). The 19 arginine residues distributed over the sequence of Ace-AMP1 are all exposed to the solvent, and therefore, most of their side chains are badly defined. Only Arg44, Arg65, Arg79, and Arg84 side chains have $\chi^{1}$ circular variances lower than 0.1 (Figure 3 ). Some of them are involved in hydrogen bonds or salt bridges. For instance, the side chain guanidinium groups of Arg43 and Arg44 form a hydrogen bond with the C-terminal group. This hydrogen bond can be related to the low-field chemical shift of the $\epsilon \mathrm{NH}$ proton of Arg43 (9.3 ppm). In 9 refined structures, the guanidinium group of Arg65 is quite close to the oxygen of the hydroxyl of Tyr $17(2.8 \AA)$. In the TOCSY cross-peak pattern of the aromatic ring, the $\mathrm{H} \delta$ protons are coupled to two nonequivalent protons and give rise to two very broad cross-peaks. At $35^{\circ} \mathrm{C}$, their line width is almost $100 \mathrm{~Hz}$. Increasing the temperature to $45^{\circ} \mathrm{C}$ leads to an increase of the line width of up to $150 \mathrm{~Hz}$ of the most downfield located cross-peak while the intensity of the second one is drastically reduced. These observations are in agreement with a restricted mobility of the Tyr17 side chain, most probably due to a hydrogen bond. In most structures, the side chain of Arg79 points toward the hydroxyl oxygen of Thr76. However, a hydrogen bond is found in only 6 structures among 15 . Finally, in 7 out of 15 structures, the guanidinium group of Arg86 is involved in a hydrogen bond with the side chain carbonyl of Asn55 (2.8 ̊). Ace-AMP1 contains two acidic residues, Asp 33 and $A s p 72$, which belong to the $\mathrm{H} 2$ and $\mathrm{H} 4$ helixes, respectively, and whose side chains are well-defined. Asp33 appears to be involved in a salt bridge with the guanidinium group of Arg6, as shown in 7 out of 15 structures.

Hydrophobic Core. The hydrophobic aliphatic residues of the four amphipatic helixes (Val7, lle10, Val11, and Val15 in helix. H1, Ile24, Leu31, Leu34, and Val37 in H2, Leu50, Val51, Val53, and Val54 in H3, and Ile69 in H4) are pointing toward the interior of the protein, generating a large and extended hydrophobic core. Unlike ns-LTPs, Ace-AMP1 contains 7 aromatic residues which are almost all located in the last helix and the C-terminal region. As shown in the superposition of the 15 structures represented in Figure 5, the conformations of aromatic residues are very well defined. All their side chains strongly interact with their near environment and display very well defined conformations as revealed by their $\chi^{1}$ circular variances which are always lower than 0.01 (Figure 3). The aromatic side chain of Tyr 17, belonging to the first helix, is located between the last turn of $\mathrm{H1}$ and the first turn of $\mathrm{H} 2$, thus facing residues Ile24 and Hle69. These three amino acids make a partially solvent-exposed hydrophobic cluster at the top of $\mathrm{H} 1$. The Phe 36 residue located in the last turn of $\mathrm{H} 2$ belongs to another hydrophobic cluster involving residues Ile3, Val7, and Leu34, which is partially exposed to the solvent. Phe66, which belongs to the last helix, is oriented toward the core of the protein, makes several contacts with $\mathrm{H} 1, \mathrm{H} 4$, and the C-terminal region, and is included in an aromatic cluster involving residues Trp82 and Trp83. The C-terminal segment contains four aromatic residues, namely Phe 77, Phe81, Trp82, and Trp83. The last three residues of this segment belong to the hydrophobic core, while Phe77 is solventexposed. Phe8 1 is in van der Waals contact with the $\mathrm{Hl}$ and $\mathrm{H} 2$ helixes and is buried in a small hydrophobic cluster involving residues Leu34 and Val37. The Trp82 residue makes contacts with helixes $\mathrm{H} 1, \mathrm{H} 2$, and $\mathrm{H} 4$, while Trp83 interacts with helixes $\mathrm{H} 3$ and $\mathrm{H} 4$ through residues Val51, Val54, and Leu60. Trp82, Trp83, and Phe66 constitute an 
$\mathbf{A}$

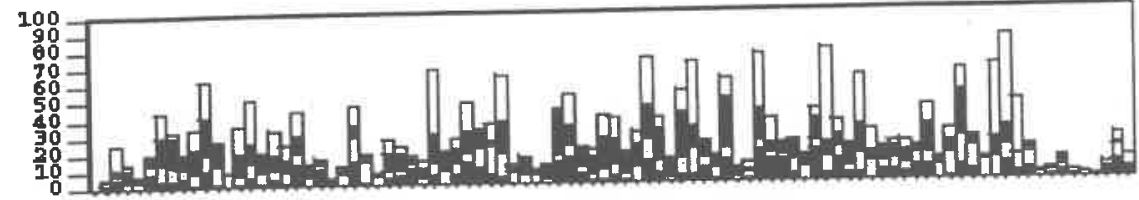

$\mathbf{B}$
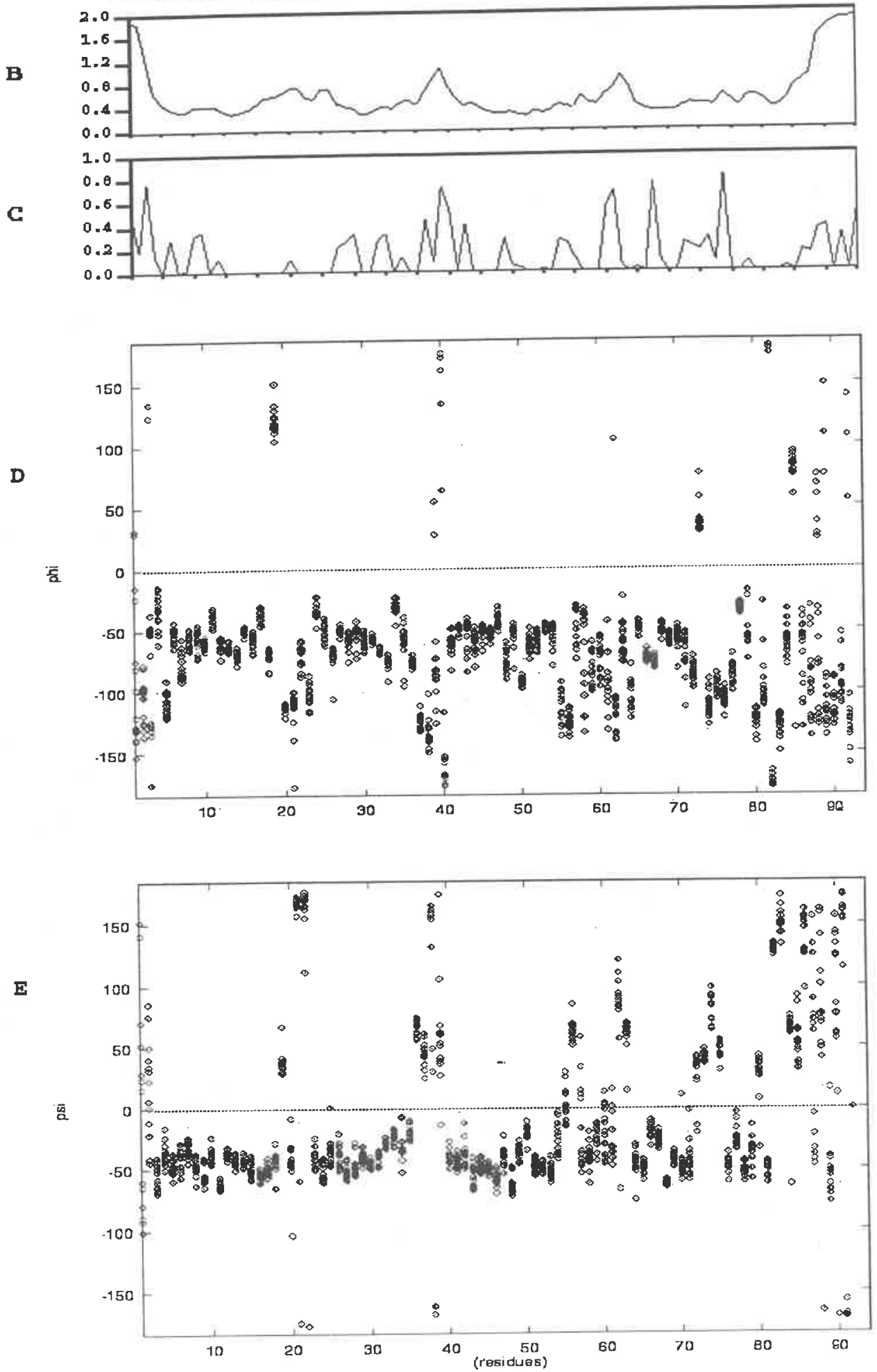

FIIURE 3. Data for the 15 best NMR structures of Ace-AMPI plotted as a function of sequence. (A) Distribution of intraresidual (black) FIGURE 3: Data for the 15 best NMR structures of Ace-AMP (light gray) NOEs by residue. (B) Average local rmsd for backbone atoms (N. C $\alpha$. C, and O) for residues $1-93$. (C) Distribution of the $\chi^{1}$ circular variance by residue. The $\chi^{\prime}$ circular variance was calculated by PROCHECK (45). (D) Distribution of the $\phi$ angle by residue. (E) Distribution of the $\psi$ angle by residue.

aromatic cluster embedded in the hydrophobic core of the protein. In all structures, the Trp 82 side chain facing the
Phe66 aromatic ring is not accessible to the solvent. Its indolic proton is involved in a hydrogen bond with the 


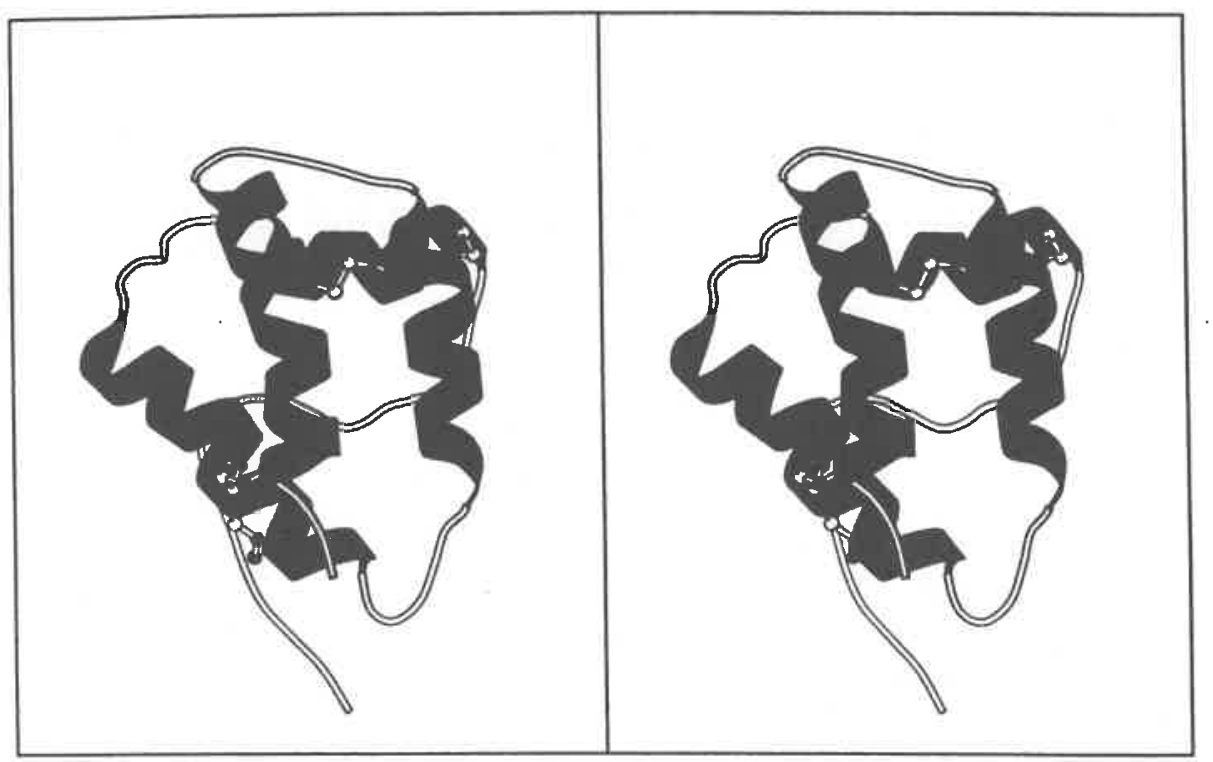

FIGURE 4: MOLSCRIPT (58) stereoview of Ace-AMP1. Helixes H1 (4-19), H2 (25-36), H3 (42-57), and H4 (65-74) and the four disulfide bridges are reported.

\begin{tabular}{clllll}
\hline \multicolumn{7}{l}{ Table 3: Side Chain Dihedral Angles for the Four Disulfide Bridges } \\
\hline \multicolumn{7}{c}{$\chi^{1}$} & \multicolumn{1}{c}{$\chi^{2}$} & \multicolumn{1}{c}{$\chi^{\mathrm{ss}}$} & $\chi^{2^{\circ}}$ & $\chi^{1^{\prime}}$ \\
\hline $4-49(14$ structures $)$ & $-103.2^{\circ}\left(31.8^{\circ}\right)$ & $9.5^{\circ}\left(40.0^{\circ}\right)$ & $-101.3^{\circ}\left(18.1^{\circ}\right)$ & $-83.5^{\circ}\left(11.8^{\circ}\right)$ & $-33.7^{\circ}\left(12.8^{\circ}\right)$ \\
$14-27(12$ structures $)$ & $-87.4^{\circ}\left(29.0^{\circ}\right)$ & $-82.1^{\circ}\left(46.7^{\circ}\right)$ & $-89.6^{\circ}\left(3.3^{\circ}\right)$ & $-38.8^{\circ}\left(19.6^{\circ}\right)$ & $-54.4^{\circ}\left(5.1^{\circ}\right)$ \\
$(3$ structures $)$ & $-162.5^{\circ}\left(2.7^{\circ}\right)$ & $73.8^{\circ}\left(2.7^{\circ}\right)$ & $100.2^{\circ}\left(3.7^{\circ}\right)$ & $-96.1^{\circ}\left(1.6^{\circ}\right)$ & $-64.3^{\circ}\left(4.5^{\circ}\right)$ \\
$28-73$ (8 structures) & $-159.3^{\circ}\left(29.0^{\circ}\right)$ & $-93.3^{\circ}\left(18.7^{\circ}\right)$ & $-94.8^{\circ}\left(17.1^{\circ}\right)$ & $-131.8^{\circ}\left(6.8^{\circ}\right)$ & $-114.0^{\circ}\left(15.9^{\circ}\right)$ \\
$(6$ structures) & $-87.9^{\circ}\left(16.9^{\circ}\right)$ & $-82.7^{\circ}\left(23.9^{\circ}\right)$ & $121.4^{\circ}\left(3.9^{\circ}\right)$ & $119.9^{\circ}\left(10.3^{\circ}\right)$ & $-102.3^{\circ}\left(11.8^{\circ}\right)$ \\
$47-89(15$ structures $)$ & $166.6^{\circ}\left(8.3^{\circ}\right)$ & $-36.4^{\circ}\left(117.7^{\circ}\right)$ & $-26.7^{\circ}\left(109.9^{\circ}\right)$ & $77.5^{\circ}\left(75.1^{\circ}\right)$ & $-91.1^{\circ}\left(56.1^{\circ}\right)$ \\
\hline
\end{tabular}
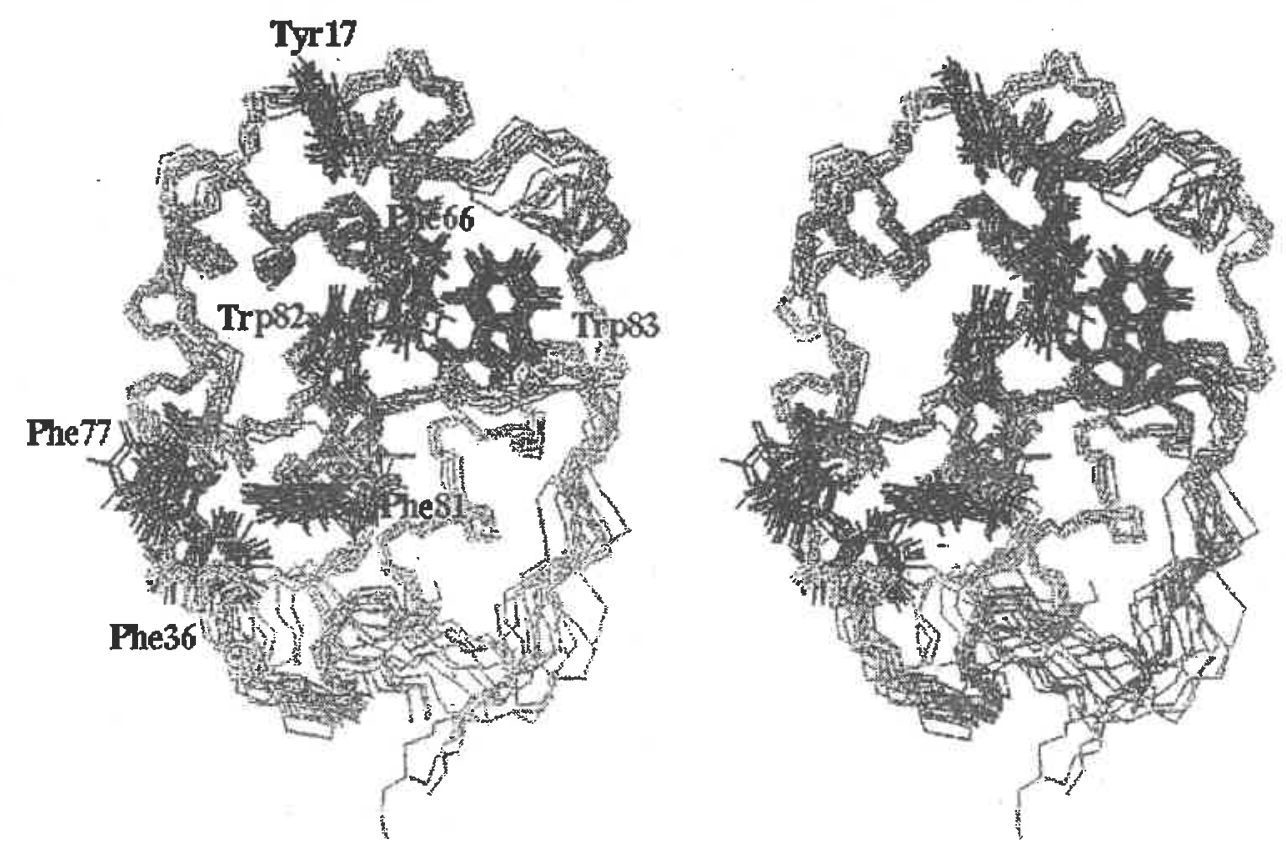

FIGURE 5: Stereoview of the 15 best NMR structures of Ace-AMP1 showing the aromatic residues and the polypeptide backbone. The structures are fitted to the $\mathrm{C} \alpha$ atoms of the four helixes.

backbone carbonyl of Phe66 and does not exchange with ${ }^{2} \mathrm{H}$ over a period of several weeks.

\section{Interactions with Phospholipids}

The possible interaction of Ace-AMPI with phospholipids was assessed using three different assays. The ability of the protein to bind individual fluorescent pyrene-conjugated phospholipids was first tested. It was found that Ace-AMP 1 did not induce a change in fluorescence of either pyr-PC or pyr-PG, while the fluorescence of both molecules increased significantly in the presence of wheat ns-LTP (Figure 6a). This result indicates that Ace-AMP1, in contrast with wheat ns-LTP, cannot associate with individual phospholipids in solution. A second assay was used to measure the release 

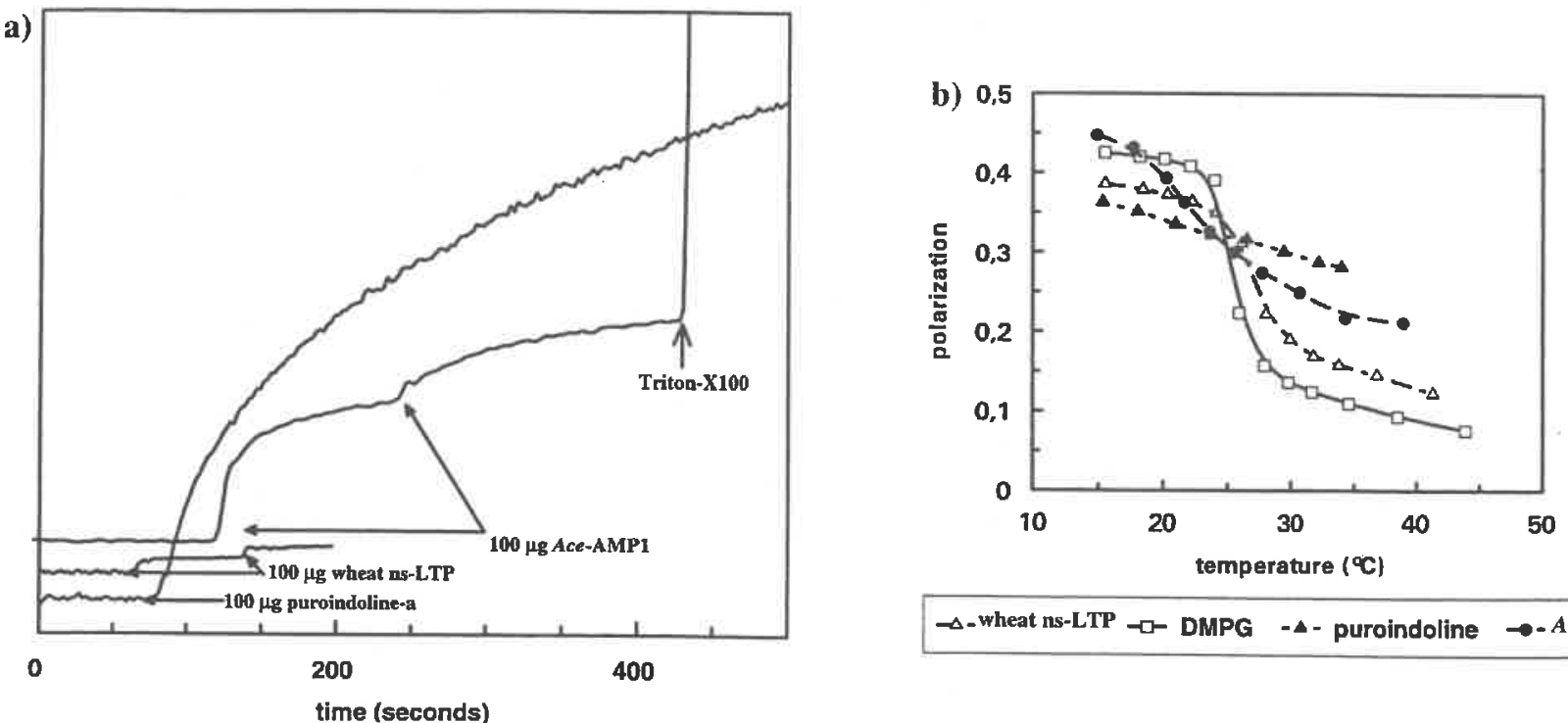

$\rightarrow$-wheat ns-LTP $\rightarrow-$ DMPG $-4-$ puroindoline $\rightarrow-$ Ace-AMP1

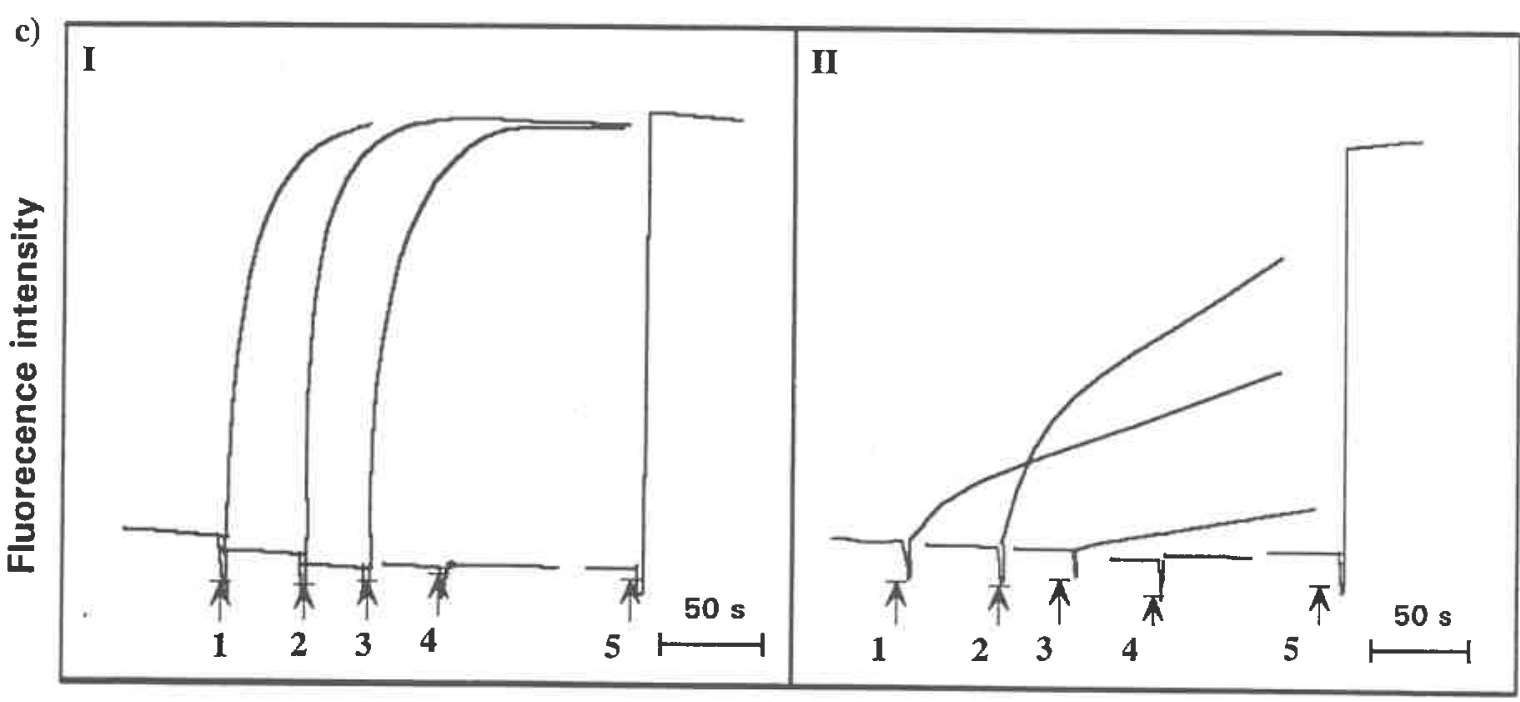

\section{Time $|s|$}

FIGURE 6: (a) Carboxyfluorescein release from liposomes consisting of a PG/PC mixture, induced by Ace-AMPl. wheat ns-LTP. and puroidoline-a. Arrows indicated the time of addition of the protein. (b) Fluorescence polarization of the hydrophobic probe, diphenylhexatriene. on gel-fluid liquid-crystalline phase transition of DMPG liposomes. (c) Binding of fluorescent pyr-PG (I) and pyr-PC (II) probes to wheat (1), maize (2), barley ns-LTPs (3), and Ace-AMPI (4). Total fluorescence was measured by adding Triton X-100 (5).

of carboxyfluorescein entrapped in artificial liposomes composed of an equimolar mixture of PG and PC. AceAMP1 was found to release carboxyfluorescein from such iposomes, indicating that it somehow interacts with the lipid bilayers (Figure 6a). In contrast, wheat ns-LTP was not active in this assay. This release of carboxyfluorescein caused by Ace-AMP1 was substantially weaker than that induced by puroindoline-a, a wheat protein known to interact strongly with bilayer vesicles (50) (Figure 6a). Finally, a last assay was set up which consisted of measuring fluorescence polarization of a lipophilic fluorescent probe embedded in acidic DMPG bilayer vesicles before and after addition of the protein. Ace-AMPl caused a decrease in cooperativity of the gel to fluid transition (Figure 6b). These effects were observed only when the amount of protein added was high (lipid/protein ratio $R_{\mathrm{i}}=1-2$ ), and in contrast with that of puroindoline-a, the phase transition was not suppressed. A slight but significant increase in the transition temperature was observed with wheat ns-LTP with no major changes of transition cooperativity. No effects on the gel-fluid phase transition of neutral DMPC were observed for both wheat ns-LTP and Ace-AMP1. The pyrene fluorescence assay was also performed without addition of the acceptor liposomes in order to probe lipid binding. Under these conditions, the protein/lipid molar ratio was $5 / 1$. No tluorescence increase was observed when Ace-AMP1 was added to pyr-PG liposomes, contrary to what was observed for wheat. barley. and maize ns-LTPs. Similar results are obtained with pyr$\mathrm{PC}$ (Figure $6 \mathrm{c}$ ). It was noteworthy that the binding of $\mathrm{PC}$ is not immediate, unlike that of pyr-PG. This result was probably due to a difference in the kinetics of the adsorption of protein to the bilayer interface. This adsorption was probably improved by the electrostatic interactions between basic ns-LTP and anionic PG. This experiment showed unambiguously that Ace-AMPI was unable to bind diacylphospholipids, unlike the other cereal ns-LTPs. However. these results do not preclude the binding of monoacylated derivatives to Ace-AMPI. 


\section{DISCUSSION}

Comparison of the Structure of Ace-AMPI with n.s-LTP Structures. Ace-AMPI shares about $32 \%$ sequence identity and about $46 \%$ sequence similarity with maize ns-LTP. These numbers fall when other ns-LTP sequences are considered (Figure 7). Nevertheless, a superposition of the global folds of Ace-AMPI and wheat (19), maize (20), and barley (22) ns-LTP solution structures reveals striking structural analogies (Figure 8). In the four proteins, the tertiary fold maintained by four disulfide bridges involves four helixes wound on a right-handed superhelix and an extended C-terminal region. Superposition of the experimental structure of Ace-AMPl in solution with that predicted by homology modeling (18) reveals the same global fold (Figure 8). The main difference is in the presence of supplementary turns in the structure in solution (residues 59-62 and 7981 ) and in the position of some aromatic side chains (Trp82 and Trp83).

The doublet Prol3-Cys14 of the H1 helix is present in the four protein sequences. and the proline residue induces a kink of about $20^{\circ}$ in their $\mathrm{Hl}$ helix. This kink is associated with high ${ }^{3} J_{\mathrm{C}_{\mathrm{i}} \mathrm{HNH}}$ coupling constants in sequence positions $i$ -2 and $i+1$, where $i$ represents the proline sequence index. Comparison of the average interhelix angles in reported nsLTP structures and Ace-AMPI (Table 4) shows that the first three helixes have the same directions in all four proteins. torming an up-down-up motif: The main difference between Ace-AMPI and the ns-LTPs seems to be located in the spatial position of helix $\mathrm{H} 4$. The precision of the three interhelix angles involving $\mathrm{H} 4$ is rather poor for Ace-AMPl structures, due to its $3_{10-}$ and $\alpha$-helical mixed characteristics. Another difference between ns-LTPS and Ace-AMPI is the presence in the last protein of one supplementary $\alpha$-helix turn involving residues Gly59-Asn62 following the H3 helix and another one involving residues Arg79-Phe81 following the $\mathrm{H} 4$ helix. The latter turn seems to be correlated with the insertion of two amino acids. Val78 and Arg 79 in AceAMP1, which are not in ns-LTPs. Val78 and Phe81 belong to the hydrophobic core and are pointing toward the interior of the protein. while Arg79 is oriented outward into the solvent.

In addition to the eight cysteine residues, several hydrophobic residues. namely Val7. Vall 1. Pro 13. Vall5. Leu31. Leu34, Val37. Ala46. Leu50. Leu60. Ile69. and Pro80. are conserved between Ace-AMPI and ns-LTP sequences. They are spread all over the different structural elements. and they interact to form the hydrophobic cluster in the core of the protein and therefore contribute to the stability of the protein scatfold. An aromatic residue. Tyr or Phe, is present in all ns-LTPs and in Ace-AMP1 at position 17 (Ace-AMPI numbering). In Ace-AMP1, a hydrogen bond is found between the Tyr 17 and Arg65 side chains. In the maize nsLTP X-ray structure. such a hydrogen bond would exist considering that the Tyrl7 hydroxyl hydrogen is close enough to the oxygen side chain of Asn64. A close analysis of the $13 \mathrm{~ns}-\mathrm{LTP}$ sequence alignments shows that a lysine or an asparagine residue is present in position 65 in 8 secutences. This observation probably indicates that the hydrogen bond involving Tyrl7 is a general feature of nsLTP structures. The Leu+2 residue of Ace-AMPI interacting with Ile 3 and Val37 is replaced by an aspartic residue in all
ns-LTP sequences. In the maize ns-LTP structure, this aspartic residuc is engaged in a salt bridge with the amino group of the $\mathrm{N}$-terminal residue. Dilferent kinds of interactions seems then to be involved in the stabilization of the $\mathrm{N}$-terminal fragment.

A fragment of 8 amino acids involving residues Arg43Arg44-Ala45-Ala146-Cys47-Xaa48-Cys49-Leu50 is strictly conserved between the maize ns-LTP and Ace-AMPI sequences (Figure 7). Similar interactions are found between Arg43-Arg44 residues and the C-terminal group in AceAMPl and Arg45-Arg46 residues and the $C$ terminus in maize ns-LTP. An aromatic residue is present in most nsLTP sequences at position 81 . In maize ns-LTP, this residue (a tyrosine) juts into the protein hydrophobic cavity, thus capping the channel. In the lipid-protein complex $(20,2 I)$, this residue participates in the stabilization of the complex via a hydrogen bond between its $\mathrm{OH}$ and the lipid carbonyl. In Ace-AMPI. this residue is replaced by a phenylalanine and its aromatic ring is in the same location as the tyrosine ring in reported solution structures of ns-LTPs. In the maize ns-LTP X-ray structure. the H3 helix interacts with the second part of the C-terminal region through a hydrogen bond between Lys54 and Thr87 residues (21). Such hydrogen bonding is not systematically found in all NMR structures of Ace-AMPI ( 7 of the 15 structures). indicating that other kinds of interactions could be involved in this region.

A striking structural feature of all known structures of nsLTP is an internal hydrophobic cavity running through the whole molecule (19-22). It is first parallel to $\mathrm{Hl}$ and then to $\mathrm{H} 4$ and is large enough to accommodate one or two aliphatic chains of a lipid $(20,21,51)$. The volume of this cavity can vary from 240 to $500 \mathrm{~A}^{3}$ in the maize ns-LTP solution structure without noticeable changes of the overall protein structure (20). Slight variations of the C-terminal fragment and side chain conformations of the residues which delineate the cavity lead to such large volume variations. We have recently shown that wheat ns-LTP can form a stable complex in solution with DMPG. a diacylphospholipid $(5 i)$. The calculated structure derived from NOE data revealed that the insertion of the lipid into the hydrophobic cavity did not entail significant changes in the protein structure architecture. The most glaring divergence between the protein and the complex concerns the position of the C-terminal tail which is pushed outward imto the solvent. Therefore, it appears that this C-terminal segment can act as a molecular cover capping the hydrophobic crevice delineated by the four helixes and modulating the accessible volume. This peculiarity may explain why these proteins are not specific and are able to transfer different hydrophobic compounds. Although most assays designed to assess the biological activity of ns-LTPs are based on the interaction with phospholipids, the natural ligands of these proteins are actually unknown. To detect the presence of such a cavity in Ace-AMPl solution structures. we have applied the program CAVITE (/8) which probes and delineates cavities inside protein structures. As shown in Figure 9. Ac'e-AMP I possesses some sparse and small calvities, but there is no continuous channel as described in ns-LTP structures. although hydrophobic residues which outline the maize nsLTP hydrophobic pocket are mostly conserved in the sequence of Ace-AMP1. This structural difference arises 


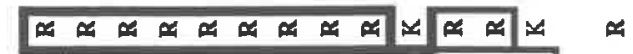

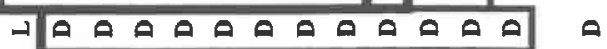
$z<n 0<<<n a d a A \theta$ \& $x$ Ho 的

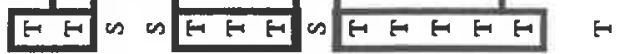

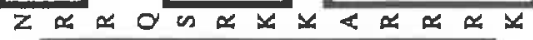

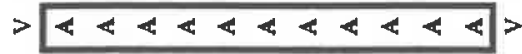
m $<00<<n<<<\sum \Sigma$ L $z z z<<00<z z \cos \theta$

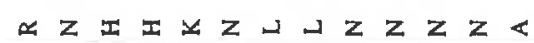

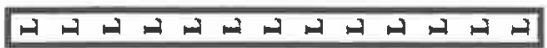

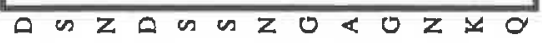
$z \propto x \simeq \propto ⿻ x \geq x \leqslant \infty 0$

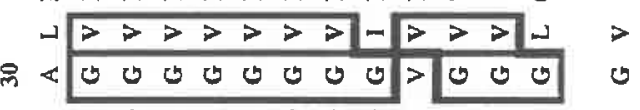

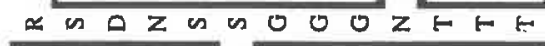

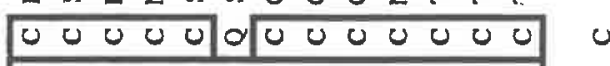
\begin{tabular}{lllllllllllll}
\hline & 0 & 0 & 0 & 0 & 0 & 0 & 0 & 0 & 0 & 0 & 0
\end{tabular} a 0 O $\ll<00<<0000 \pi 00$ $-\cos$ as is as $A+\lambda>$. 2 in

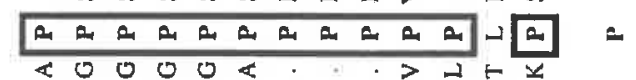

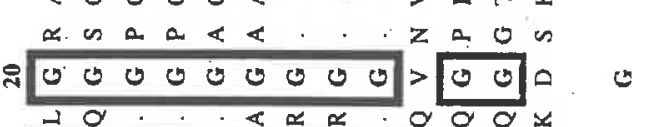



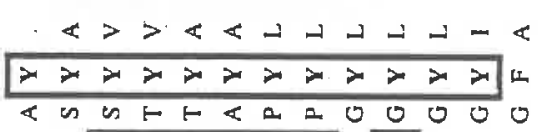

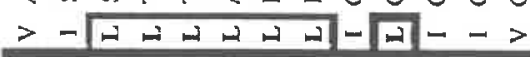

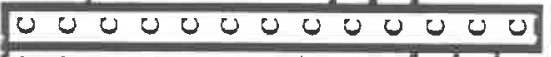

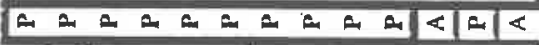

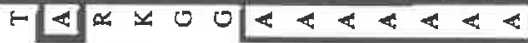
$>->\Sigma>-\lrcorner-\lrcorner\lrcorner\lrcorner>\varangle$

$9-<-x<<00 x<z z y$

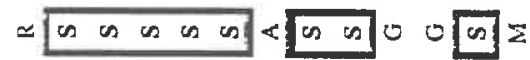

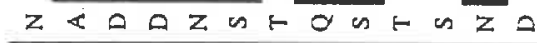

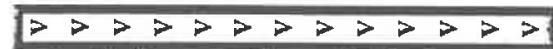

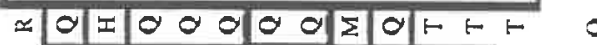
a 0 \begin{tabular}{lllllllllll}
\hline & 0 & 0 & 0 & 0 & 0 & 0 & 0 & 0 & 0 & 0
\end{tabular}

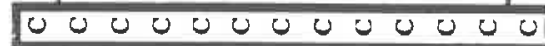
- naztatetanta $z--\lrcorner--\lrcorner\lrcorner-\lrcorner\lrcorner\lrcorner>$ $-0<1 . \quad<<<0><<<$

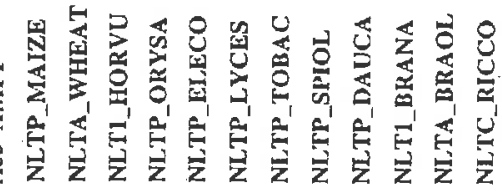

z

$z z \cdot \gamma$ a $z$ o $\alpha$ I $>\approx x$ I $->>-P>>>>>>-$

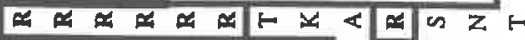
80 os en un as un uzz \begin{tabular}{llllllllllllll}
\hline & 0 & 0 & 0 & 0 & 0 & 0 & 0 & 0 & 0 & 0 & 0 & 0
\end{tabular}

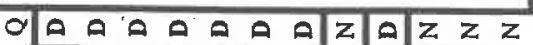

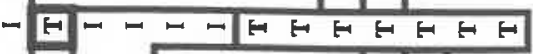

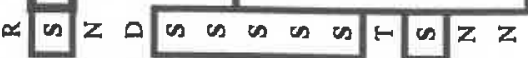

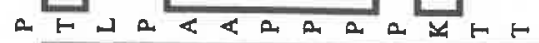

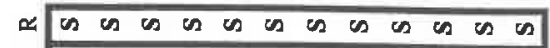
3 サローロロローロローロ>

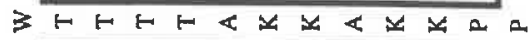
ए

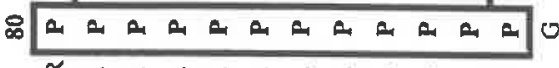
幽

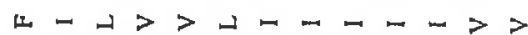

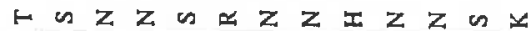
$z>>>>>>>>10$

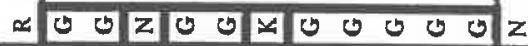
$\begin{array}{llllllllllllll}0 & 0 & 0 & 0 & 0 & 0 & 0 & 0 & 0 & 0 & 0 & 0 & 0\end{array}$

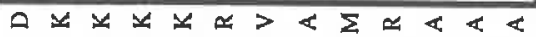
ar in a n u u n 0 u $0<x<<$

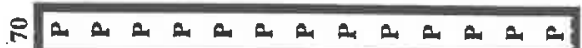



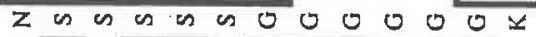

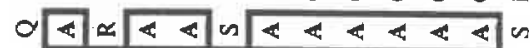
1 $4<4<4<<<<<41$


๑.

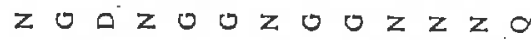

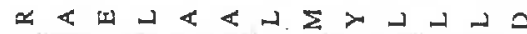

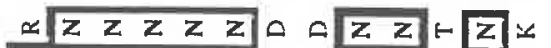
8

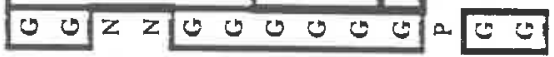


$\simeq 000004 \alpha<+\% \alpha \pi$ $z<x \propto \approx$ on z z z z $z$ z

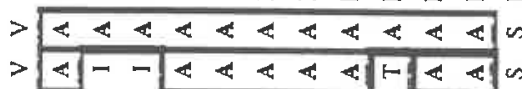

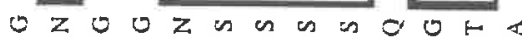

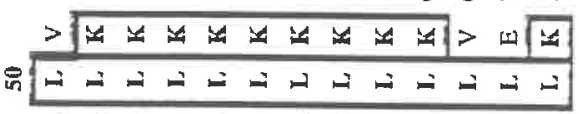

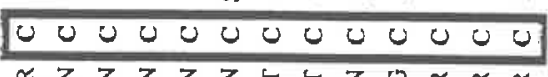

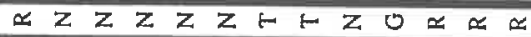
\begin{tabular}{lllllllllllllll}
\hline & 0 & 0 & 0 & 0 & 0 & 0 & 0 & 0 & 0 & 0
\end{tabular}

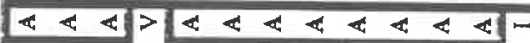
的

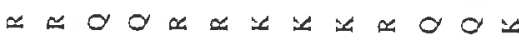

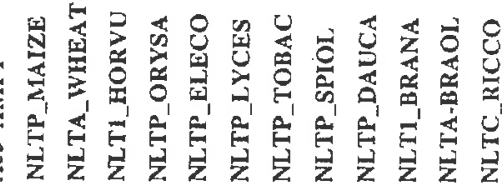

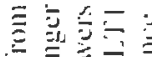

$\hat{F}$

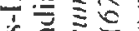

$>$

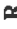

¿ 人ิڤ

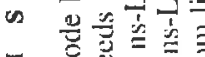

$m$

苛产芯

$\rightarrow$

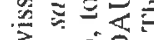

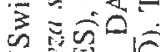

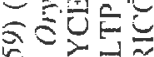



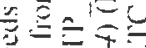



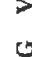

彭声

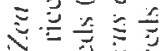

言

$\approx$

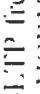

$-$

4



4

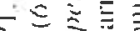

車

要言

$z$

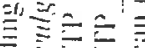

$\therefore$ =

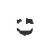

要这

-

$\overline{\underline{B}}$

列

4

$4 \quad \bar{\equiv}-1 \equiv$

政

主玄就

过

要

0 ن

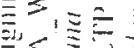

ن

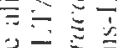

를

氧高

穴



路

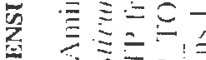



$\because-\div$ 兰音至文

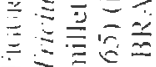






FIGURE 8: Comparison of the Ace-AMP1 global fold with that of ns-LTPs. (a) Superposition of Ace-AMP1 (magenta) with wheat ns-LTP (magenta) with maize ns-LTP (green) (20). (c) Superposition of Ace-AMPI (magenta) with AMPI (mganta) with Ace-AMPI as determined by homology modeling (green-blue barley (I8)

Table 4: Average Interhelix Angles in Maize, Wheat, and Barley ns-LTPs and Ace-AMPI Structures

\begin{tabular}{ccccc}
\multicolumn{7}{c}{ ns-LTPs and Ace-AMPI Structures } \\
\hline helixes & maize ns-LTP & wheat ns-LTP & barley ns-LTP & Ace-AMPI \\
\hline $2-1$ & -146 & -143 & -146 & $-1+2$ \\
$3-1$ & -31 & -22 & -24 & -33 \\
$3-2$ & -141 & -143 & -144 & $-1+5$ \\
$4-1$ & 124 & 132 & 123 & 80 \\
$4-2$ & -78 & -72 & -64 & -86 \\
$4-3$ & 140 & 145 & 150 & 108 \\
\hline
\end{tabular}

from the presence of bulky residues Phe66, Trp82, and $\operatorname{Trp} 83$ which are found only in the Ace-AMPI sequence. This is shown in Figure 10 where the side chains of these three aromatic residues are displayed within the hydrophobic cavity of maize ns-LTP, whose structure was fitted on the $\mathrm{C} \alpha$ coordinates of Ace-AMP1. Actually, the aromatic rings of residues Phe66 and Trp82 are oriented toward the interior of the protein obstructing the channel. The position of the tryptophan residues in the hydrophobic core of the protein is consistent with fluorescence data. The emission peak around $330 \mathrm{~nm}$ (result not shown) is close to the emission of a tryptophan in a hydrophobic environment. The absence of any continuous cavity inside the protein structure may be related to its incapacity to transfer lipids between membrane in vitro and to bind diacylphospholipids. However, the tw solution structures of complexes of barley ns-LTP-palmi toylCoA (23) and wheat ns-LTP-DMPG (5I) showed th: insertion of bulky lipids induces structural rearrangement 0 the protein structure. In the case of barley ns-LTP, significant swelling of the structure was observed. In th DMPG complex, the only noticeable difference between th free and complexed structures was a movement of th C-terminal region. According to these observations. w cannot completely exclude the possibility of a structur: change of Ace-AMPl taking place upon interaction wi lipidic membranes.

Interactions of Ace-AMPI with Lipids. The differe studies performed to evaluate the ability of Ace-AMP1 interact with phospholipids show unambiguously that. contrast with other plant ns-LTPs, Ace-AMPl is unable bind diacylphospholipids. These results are in agreeme 

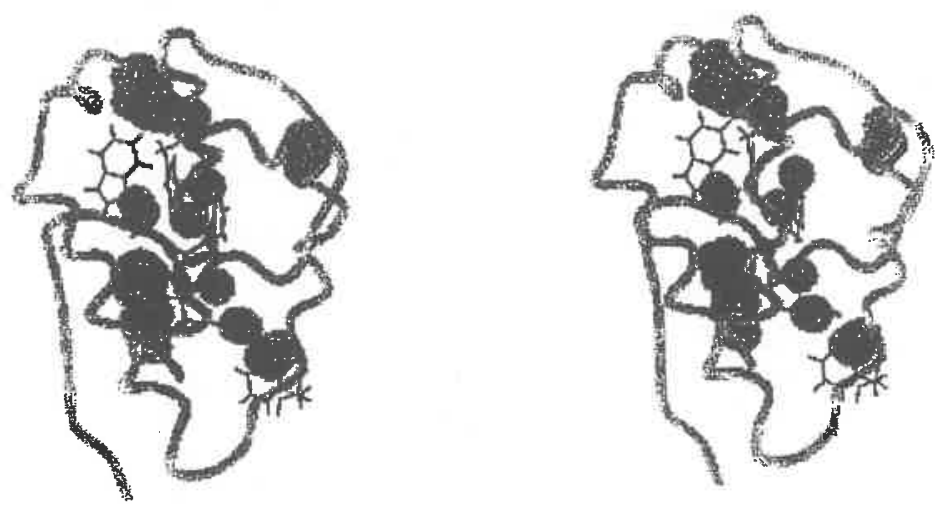

FIGURE 9: Stereoview of small cavities inside Ace-AMP1. The backbone is represented as a gray tube, and aromatic residues are indicated in black. The cavities are shown as dark gray spaces.
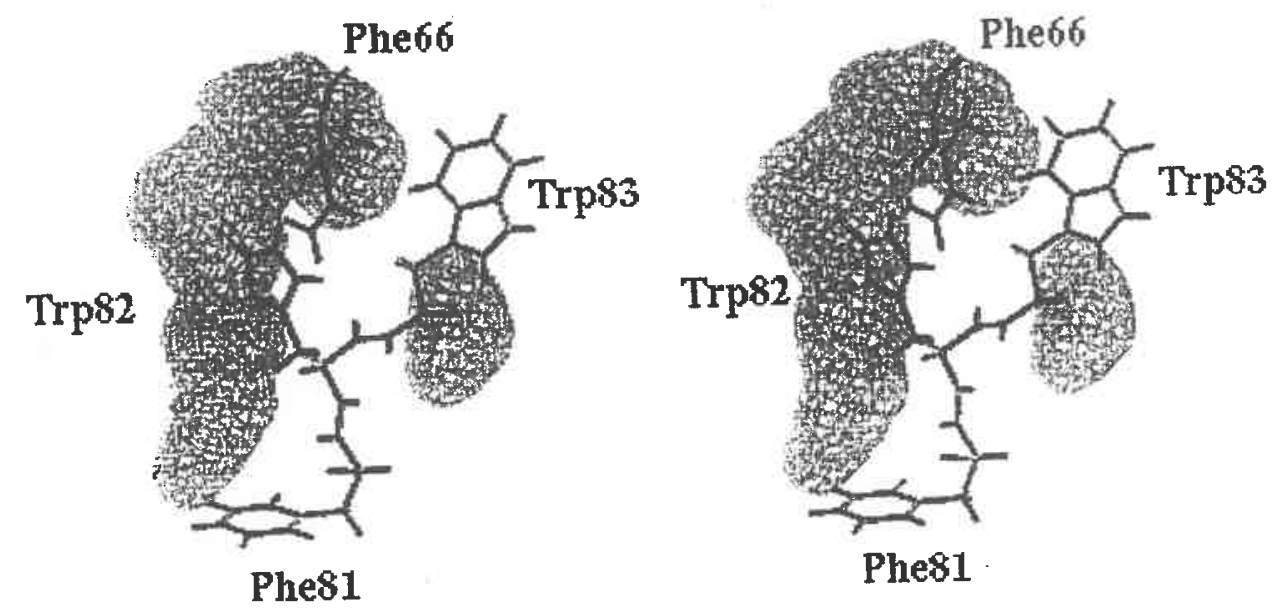

FIGURE 10: Stereoview of the maize ns-LTP cavity with indications of the positions of the aromatic residues of Ace-AMP1 (Phe66. Phe81. Trp82, and Trp83).

with previous results which demonstrated that Ace-AMP1 could not transfer phospholipids between mitochondria and Iiposomes (14) and with our structural data which show that io cavity is present in this protein. However. Ace-AMPI can interact with bilayer vesicles composed of an anionic phospholipid. phosphatidylglycerol. as shown by tluorescence polarization experiments with fluorescent membraneembedded probes. This interaction is apparently stronger with Ace-AMPI than with wheat ns-LTP. The decrease in cooperativity of the gel-fluid phase transition of the phospholipid membrane indicates that Ace-AMPl is capable of senetrating slightly into the hydrophobic core of lipid layers. This effect is more pronounced with puroindolinea. a wheat protein structurally related to plant ns-LTPs (52) which is capable of deeply penetrating into lipid bilayers (50). This is consistent with our observation that puroindoline-a is more efficient than Ace-AMPI in releasing carboxyfluorescein from the lumen of liposomes. Hence, although Ace-AMPl clearly interacts with phospholipid membranes. it is not particularly potent in disturbing or vermeabilizing such membranes in comparison to other oteins such as puroindolines. As noted previously (14), the antifungal activity of Ace-AMPI cannot be based on lipid transfer activity as the protein is unable to transfer individual lipids. On the other hand, it is also unlikely that Ace-AMP 1 exerts its antifungal effect by interacting directly with phospholipid membranes. Indeed, if lipid interaction would be the basis of the antifungal activity of Ace-AMPI, one would expect puroindolines to exert an even stronger antifungal activity than Ace-AMPI. However, antifungal activity assays show that puroindoline-a is significantly less potent than Ace-AMPI in inhibiting fungal growth, especially in the presence of salt (W.F. Broekaert, unpublished results). Another difference between Ace-AMPI, both puroindolines. and ns-LTPs is the fact that puroindolines and ns-LTPs can potentiate the antifungal activity of membrane-disturbing proteins called thionins whereas Ace-AMPI cannot (13: W. F. Broekaert. unpublished results). For all these reasonis. we favor the working hypothesis that Ace-AMPI does not affect fungal growth via direct protein-lipid interactions but rather via protein-lipid interactions mediated by a membrane receptor.

Ace-AMP1 is the only known protein of the ns-LTP family which contains such a high number of positive residues (19 arginines). Maize ns-LTP, for instance, contains only 8 basic residues. In the Ace-AMPI structure, although the arginine residues are well spread all over the sequence. at least 12 of them are oriented toward the C-terminal region. For the maize ns-LTP protein, we have shown that most of these residues are oriented toward the $\mathrm{C}$-terminal region. thus constituting a possible interaction site of ns-LTPs with acidic lipid layers (20). Such a conclusion could therefore be extended to Ace-AMP1.

In addition to Ace-AMPl and ns-LTPs, other more distantly related proteins also seem to have adopted a folding based on a bundle of four cystine-stabilized $\alpha$-helixes. These proteins include puroindolines (52), $2 \mathrm{~S}$ albumines (53), and probably also related $\alpha$-amylase/protease inhibitors from 
3636 Biochemistry, Vol. 37, No. 11, 1998

cereal seeds (54). It is interesting to note that puroindolines (52) and $2 \mathrm{~S}$ albumines (55) have also been shown to interact with phospholipid membranes. Hence, interaction with membranes seems to be a general property of this protein superfamilly, although the way they interact with membranes apparently differs significantly among the different superfamilly members.

In conclusion, the four known three-dimensional structures of proteins extracted from different plant seeds (wheat, maize, barley, and onion) exhibit very similar folds. The organization of their hydrophobic cores appears to be a determinant of their capacity to bind lipids. In proteins from cereal seeds that are actual ns-LTPs, there is an open internal cavity that can readily expand and accommodate various hydrophobic substrates. The presence of such a large cavity in proteins is quite remarkable and raises questions about the folding and the stability of their structures which will be discussed elsewhere (J. Poznanski, unpublished experiments). In AceAMP1, this cavity is blocked by aromatic residues and the protein neither binds nor transfers lipids. Lipid binding and intermembrane transfer properties are then closely related. It should be now interesting to determine structures of proteins extracted from others seeds and more generally from different parts of plants. It is now established that there are generally several LTP genes per plant genome which encode for isoforms with distinct patterns of expression $(56,57)$. A systematic analysis of their structures and of the corresponding lipid binding and transfer properties as well as antibacterial and antifungal activities should clarify the biological role of these proteins. On the basis of the extracellular location of the EP2 protein secreted by embryogenic cell cultures of carrot and identified as a LTP, Sterk et al. (24) have proposed for this protein a role in the surface defense of plants in which the protein transports cutin monomers to the apoplast. Such a role would be different from lipid transfer between membranes. Preliminary results (D. Marion, personal communication) confirm that ns-LTPs are able to bind such oxygenated fatty acids. Considering that various proteins from microorganisms and from animals with different molecular weights, different specificities, and possibly different structures are also capable of transferring lipids between membranes, this property seems to be rather general and not clearly related to a biological function. Plant nsLTPs which can bind various lipids and hydrophobic compounds and have various patterns of expression and various locations appear as multifunctional proteins. They could be involved in several different mechanisms of binding and transport of substrates, essential for the development and the surface defense of these plants, toward sites which are not necessarily membranes.

On the basis of the growth inhibition of plant pathogens by several isoforms of barley ns-LTPs (13) and on the basis of the antifungal properties of Ace-AMP1, a different role has been proposed for other proteins which are structural analogues of ns-LTPs but which would contribute differently to the plant defense by acting on pathogens. This property seems to be more related to their interactions with membrane structures than to their capacity to transfer lipids. The existence of such a family of proteins having similar structures but different functions is puzzling and could indicate that plants use various and potent mechanisms to defend against pathogens and environmental injuries.

\section{ACKNOWLEDGMENT}

We thank Geneviève Compoint for her technical assistance in the fluorescence experiments.

\section{SUPPORTING INFORMATION AVALABLE}

Table containing the ${ }^{1} \mathrm{H}$ chemical shifts of Ace-AMP1 (2 pages). Ordering information is given on any current masthead page.

\section{REFERENCES}

Stuart, L. S., and Harris, T. H. (1942) Cereal Chem. 19, 288-300. Manners, D. J., and Marshall, J. J. (1973) Phytochemistry 12, 547553.

Leah, R., Tommerup, H., Svendsen, I., and Mundy, J. (1991) J. Biol. Chem. 266, 1564-1573.

Vigers, A. J., Roberts, W. K., and Selitrennikoff, C. P. (1991) Mol. Plant-Microbe Interact. 4, 315-323.

Roberts, W. K., and Selitrennikoff, C. P. (1986) Biochim. Biophys. Acta 880, 161-171.

Broekaert, W. F., Mariën, W., Terras, F. R. G., De Bolle, M. F. C., Proost, P., Van Damme, J., Dillen, L., Claeys, M., Rees, S. B., Vanderleyden, L., and Cammue, B. P. A. (1992) Biochemistry $31,4308-4314$.

Cammue, B. P. A., De Bolle, M. F. C., Terras, F. R. G., Proost, P., Van Damme, J., Rees, S. B., Vanderleyden, L., and Broekaert, W. F. (1992) J. Biol. Chem. 267, 2228-2233.

Duvick, J. P., Rood, T., Rao, A. G., and Marshak, D. R. (1992) J. Biol. Chem. 267, 18814-18820.

Terras, F. R. G., Goderis, I. J., Van Leuven, F., Vanderleyden, J., Cammue, B. P. A., and Broekaert, W. F. (1992a) Plant Physiol. $100,1055-1058$.

Terras, F. R. G., Torrekens, S., Van Leuven, F., Osborn, R. W., Vanderleyden, J., Cammue, B. P. A., and Broekaert, W. F. (1993) FEBS Lett. 316, 233-240.

Terras, F. R. G., Eggermont, K., Kovaleva, V., Raikhel, N. V., Osborn, R. W., Kester, A., Rees, S. B., Vanderleyden, J., Cammue, B. P. A., and Broekaert, W. F. (1995) Plant Cell 7, $573-588$.

Terras, F. R. G., Schoofs, H. M. E., De Bolle, M. F. C., Van Leuven, F., Rees, S. B., Vanderleyden, J., Cammue, B. P. A.; and Broekaert, W. F. (1992b) J. Biol. Chem. 267, 15301-15309.

Molina. A., Segura, A., and Garcia-Olmedo, F. (1993) FEBS Lett. $316,119-122$.

Cammue, B. P. A., Thevissen, K., Hendriks, M., Eggermont, K., Goderis, I. J., Proost, P., Van Damme, J., Osbom, R. W., Guerbette, F., Kader, J. C., and Broekaert, W. F. (1995) Plant Physiol. 109, 445-455.

Nakamura, K., and Matsuoka, K. (1993) Plant Physiol. 101, 1-5. Bednarek, S. Y., and Raikhel, N. V. (1991) Plant Cell 3, 11951206.

Neuhaus, J. M., Sticher, L., Meins, F., Jr., and Boller, T. (1991) Proc. Natl. Acad. Sci. U.S.A. 88, $10362-10366$.

Gomar, J., Sodano, P., Ptak, M., and Vovelle, F. (1997) Folding Des. 2, 183-192.

Gincel, E., Simorre. J. P., Caille, A., Marion, D., Ptak, M., and Vovelle, F. (1994) Eur. J. Biochem. 226, 413-422.

Gomar, J., Petit, M. C., Sodano, P., Sy, D., Marion, D., Kader, J. C. Vovelle, F., and Ptak, M. (1996) Protein Sci. 5, 565-577. Shin, D. H., Lee, J. Y., Hwang, K. Y., Kim, K. K., and Suh, S. W. (1995) Structure 3, 189-199.

Heinemann, B., Andersen, K. V., Nielsen, P. R., Bech, L. M., and Poulsen, F. M. (1996) Protein Sci. 5, 13-23.

Lerche, M. H., Kragelund B. B., Bech, L. M., and Poulsen, F. M. (1997) Structure 5, 291-306.

Sterk, P., Booij, H., Schellekens, G. A., Van Kammen, A., and De Vries, S. C. (1991) Plant Cell 3, 907-921.

Garcia-Olmedo, F., Molina, A., Segura, A., and Moreno, M. (1995) Trends Microbiol. 3, 72-74.

Petit, M. C., Sodano, P., Marion. D., and Ptak, M. (1994) Eur. J. Biochem. 222, 1047-1054. 
Record, E., Asther, Mi., Marion, D., and Asther M. (1995) Biochim. Biophys. Acta 1256, 18-24.

Wilschut, J. (1982) in Les Editions INSERM (Leserman, L. D., and Barbet, J., Eds.) p 137, INSERM, Paris.

States, D. J., Haberkorn, R. A., and Ruben, D. J. (1982) J. Magn. Reson. 48, 286-292.

Bax, A., and Davis, D. G. (1985) J. Magn. Reson. 65, 355-360.

Marion, D., Ikura, M., and Bax, A. (1989) J. Magn. Reson. 84. $425-430$

Shaka, A. J., and Freeman, R. (1983) J. Magn. Reson. 5/, 169173.

King, G., and Wright, P. E. (1983) J. Magn. Reson. 54, 328-332.

Piotto, M., Saudek, V., and Sklenar, V. (1992) J. Biomol. NMR 2 , $661-665$.

Brown, S. C., Weber, P. L., and Mueller, L. (1988) J. Magn. Reson. $77,166-169$.

Nilges, M., Clore, G. M., and Gronenborn, A. M. (1988) FEBS Lett. 229, 317-324.

Güntert, P., Braun, W., and Wüthrich, K. (1991) J. Mol. Biol. 217, $517-530$.

Güntert, P., and Wuithrich, K. (1991) J. Biomol. NMR 1, 447456.

Güntert, P., Berndt, K. D., and Wüthrich, K. (1993) J. Biomol. NMR 3, 601-606.

Eccles, C., Güntert, P., Billeter, M., and Wüthrich, K. (1991) J. Biomol. NMR 1, 111-130.

Szyperski, T., Güntert, P., Otting, G.. and Wüthrich, K. (1991) J. Magn. Reson. 99, 552-560.

Brünger, A. T. (1992) The X-PLOR sofnvare manual version 3.I, Yale University, New Haven, CT.

Brooks, B. R., Bruccoleri, R. E., Olafson, B. D., States, D. J., Swaminathan, S., and Karplus, M. (1983) J. Comput. Chem. 4. $187-217$.

Hutchinson, E. G., and Thornton, J. M. (1996) Protein Sci. 5, 212220.

Laskowski, R. A.; MacArthur, M. W., Moss. D. S.. and Thornton, J. M. (1993) J. Appl. Crystallogr. 26, 283-291.

Wüthrich, K. (1986) NMR of proteins and acid nucleics, Wiley. New York.

Sodano, P., and Ptak, M. (1995) J. Bionol. Struct. Dir. 12, 10091022.

Laskowski, R. A.. Rullmann. J. A. C., MacArthur. M. W., Kaptein. R., and Thornton, J, M. (1996) J. Biomol. NMR 8, 477-486.

Richardson, J. S. (1981) Adv. Protein Chem. 34, 168-339.
Dubreil; L., Compoint, J. P., and Marrion. D. (1997) J. Agric. Fosd Chem. 45, 108-I16.

Sodano, P., Caille. A., Sy, D., de Person, G., Marion, D.. and Ptak. M. (1997) FEBS Lett. 416, 130-134.

Le Bihan, T., Blochet, J. E., Désormeaux, A.; Marion, D., and Pézolet, M. (1996) Biochemistry 35, 12712-12722.

Rico, M., Bruix, M., Gonzales, C., Monsalve, R. I., and Rodriguez, R. (1996) Biochemistry 35, 15672-15682.

Kreis, M., Forde, B. G., Rahman, S., Miflin, B. J., and Shewry, P R. (1985) J. Mol. Biol. 183, 499-502.

Onaderra, M., Monsalve, R. I., Mancheno, J. M., Villalba, M. Marinez del Pozo, A., Gavilanez, J. G., and Rodriguez, R. (1994) Eur. J. Biochem. 225, 609-615.

Fleming, A. J., Mandel, T., Hofman, S., Sterk, P., De Vries, S. C., and Kuhlmeier, C. (1992) Plant J. 2, 855-862.

Thoma, S., Hecht, U., Kippers, A., Botella, J., De Vries, S., and Sommerville, C. (1994) Plant Physiol. 105, 35-45.

Kraulis, P. J. (1991) Acta Crystallogr., Sect. B: Struct. Sci. 48 $115-116$.

Tchang, F., This, P., Stiefel, V., Arondel, V., Morch, M. D., Pages M., Puigdomenech, P., Grellet, F., Delseny, M., Bouillon, P.. Huet, J. C., Guerbette, F., Beauvais-Cante, F., Duranton, H. Pernolet, J. C., and Kader, J. C. (1988) J. Biol. Chem. 263. $16849-16855$

Désormeaux, A., Blochet, J. E., Pézolet, M., and Marion, D. (1992)Biochim. Biophys. Acta 1121, 137-152.

Mundy, J., and Rogers, J. C. (1986) Planta 169, 51-63.

Yu. Y. G., Chung, C. H., Fowler, A., and Suh, S. W. (1988) Arch. Biochem. Biophys. 265, 466-475.

Campos, F. A., and Richardson, M. (1984) FEBS Lett. 167, 221 225.

Torres-Schuman, S., Gogoy, J. A., and Pintor-Toro, J. (1992) Plant Mol. Biol. 18, 749-757.

Masuta, C., Furuno, M., Tanaka, H., Yamada, M., and Koiwai. A. (1992) FEBS Lett. 311, 119-123.

Bernhard, W. R., Thoma, S., Botella, J., and Somerville. C. R. (1991) Plant Physiol. 95, 164-170.

Soufleri, I. A., Vergnolle, C., Miginiac, E.. and Kader. J. C. (1996) Planta 199. 229-237.

Pyee. J., and Kolattukudy, P. E. (1995) Plant J. 7. 49-59.

Tsuboi, S., Suga, T., Takishima, K., Mamiya. G.. Matsui. K.. Oseki. Y.. and Yạmada, M. (1991) J. Biochem. 110. 823-831.

B 19723515 
